\title{
MANCHESTER
}

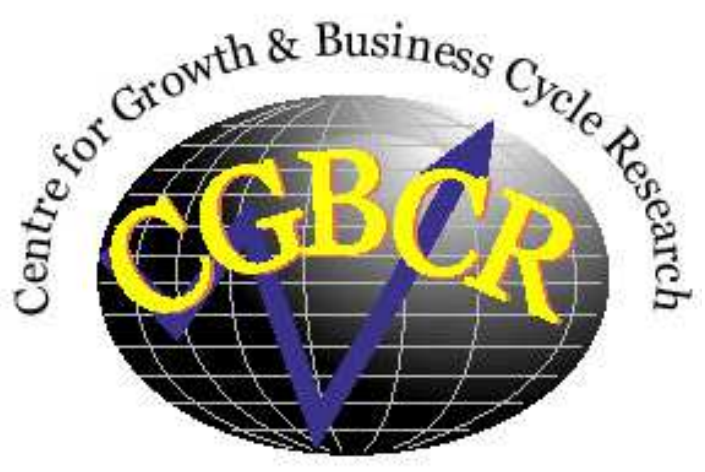

Discussion Paper Series

\section{Financial Development and Economic Growth: The Role of Financial Liberalization \\ By}

\section{Zeeshan Atiq and M. Emranul Haque}

Centre for Growth and Business Cycle Research, Economic Studies, University of Manchester, Manchester, M13 9PL, UK

January 2015

Number 201

Download paper from:

http://www.socialsciences.manchester.ac.uk/cgbcr/discussionpape rs/index.html 


\title{
Financial Development and Economic Growth: The Role of Financial Liberalization
}

\author{
Zeeshan Atiq ${ }^{\mathrm{a}, \mathrm{b}}$ and M. Emranul Haque*a \\ ${ }^{\mathrm{a}}$ Department of Economics and Centre for Growth and Business Cycles Research, The Unversity of \\ Manchester, UK \\ ${ }^{\mathrm{b}}$ Department of Economics, University of Karachi, Pakistan
}

January 20, 2015

\begin{abstract}
This paper argues that excessive liberalisation causes financial development to lose its effectiveness in generating economic growth. We investigate the hypothesis through a dynamic panel analysis for 88 countries for the period of 1973 - 2005 using a comprehensive financial development indicator constructed through principal component analysis of five different indicators used in the literature. For financial liberalisation, we use an aggregate index and its seven disaggregated components. The results indicate that the positive effect of financial development on long-run growth continues to decline as the financial sector becomes more liberalised. Our results are robust to changes in the financial development indicators and the disaggregation of the financial liberalisation index.
\end{abstract}

JELClassification E44,G28,O16, O11

Keywords Financial Sector Liberalisation; Financial Development; Economic Growth

\footnotetext{
*Corresponding author: M. Emranul Haque, Senior Lecturer, Department of Economics, The University of Manchester, Oxford Road, Manchester M13 9PL, Tel: +44 161275 4829; E-mail address:emranul.haque@manchester.ac.uk
} 


\section{Introduction}

Until recent financial crisis, the dominant view in the finance-growth literature was that more financial development results in higher levels of economic growth, mainly through its impact on productivity growth (King and Levine (1993a), King and Levine (1993b), Levine (1997), Beck, Levine and Loayza (2000); Benhabib and Spiegel (2000); Aghion et al. (2005); Ang (2008)). Further, it was largely accepted that high levels of financial development reflect sound policies and institutions. However, recent evidence suggests that countries that have the most advanced financial sector are at the heart of the financial crisis. They may have financial systems that are "too large" and these exist not because of good policies and institutions, but rather because of poor regulatory systems (Rousseau and Wachtel (2011);Arcand et al. (2012)). Moreover, the post-crisis literature discussing the reasons of the meltdown of the financial system finds root in the deficiencies in financial sector regulation (Laeven et al., 2010).

This paper contributes to the finance-growth literature by examining the role of financial development on growth conditional on the extent of financial sector liberalisation (i.e., deregulation). Hence, besides looking at the direct effects of financial development and liberalisation on growth, we address two important questions: whether the growth effect of financial development is conditional on the level of financial liberalization; and whether excessive liberalization is associated with an apparent breakdown of the relationship between finance and growth. We investigate these questions by employing a multiplicative interaction model, where the effect of interaction between financial sector liberalisation and financial development on economic growth is analysed. We focus mainly on the impact of liberalisation reforms that have taken place in the form of lessening reserve requirements, controls on interest rates, entry barriers, state ownership, banking regulation and restrictions on capital markets on economic growth. This analysis is of great interest in the context of the recent crises and future actions required on the part of countries to deal with these problems.

Following Schumpeter (1934), McKinnon (1973) and Shaw (1973) proposed 'financial liberalisation thesis'. They argued that repressive policies like setting interest rates affect the efficiency of the financial sector that affects economic growth adversely. Using cross-sectional data for 80 countries over the period 1960-1989, the findings of King and Levine (1993a) supports this view by showing that financial development stimulates both contemporaneous and future rates of eco- 
nomic growth through raising the rate of capital accumulation and its efficiency. Further, albeit with some exceptions, most of the literature on financial structure supports the financial services view that both banks and stock markets are important to economic growth (Arestis and Demetriades (1997); Rousseau and Wachtel (2000); Beck et al. (2000); Beck and Levine (2002); Beck and Levine (2004)).

In particular, the endogenous growth literature argues that finance reduces informational frictions and generates an external effect on aggregate investment efficiency which in turn offsets the notion of decreasing marginal productivity of capital (Greenwood and Jovanovic (1990); Bencivenga and Smith (1991)). King and Levine (1993b) in their model assume the role of the financial system in the evaluation of projects and diversification of the risks associated with innovation. Their analysis of the experience of five liberalised countries reveals an important role of the financial sector in the acceleration of economic growth through its impact on innovation.

Contrary to the above, there are studies that find either no or very weak support for the role of financial development on growth. For instance, Lucas (1988) believe that the growth finance literature "over-stresses" the importance of financial structure in the economic development process. On the middle ground, few favour the role of financial development in economic performance but assume the financial development as a necessary but not sufficient condition (Holzmann, 1997). Moreover, a large part of the literature conditions the positive impact of financial development to other factors, for example, legal origin (Porta et al., 1996), institutional quality (Tressel and Detragiache, 2008), functioning of political institutions (Roe and Siegel, 2008), level of income (Odedokun, 1996), etc. Cojocaru et al. (2011), using data over 1990-2008, provide evidence of the positive impact of financial development for the communist countries of Central and Eastern Europe and the commonwealth. However, they observe that this positive relationship becomes insignificant when the level of inflation is high.

There is also wariness found in the literature on the "one size fits all" assumption and the monotonic relationship between finance and growth. For example, Deidda and Fattouh (2002), using threshold model over the data of King and Levine (1993a) find an insignificant relationship for developing countries, whereas, the relationship is significant and positive for developed countries. Rioja and Valev (2007) divided a sample of 74 countries into three regions over the period 1961-1995. Among their defined regions of financial depth, at low levels they find no significant relationship between finance and growth, for medium level there is strong and positive relation- 
ship, and for high level they find weak but positive relationship. Arcand et al. (2012) using the private credit to GDP ratio as a measure of financial depth, conclude that countries with a small and medium sized financial sector benefit from increased financial depth, whereas, the effect of the size of the financial sector vanishes as the size of financial sector reaches to $80-100 \%$ of GDP.

The issue of causality is another source of disagreement regarding the relationship between finance and growth. Demetriades and Hussein (1996) find little support for the leading role of finance in economic growth. They find bi-directionality and in some cases reverse causation. Using a GMM panel estimator to address the issue of causality, Levine et al. (2000) conclude that financial development has a first order effect on long-run growth. However, a re-examination of their analysis by Favarra (2003), using cross sectional and panel data analysis, show no evidence of causality running from financial deepening to GDP growth.

Our study also contributes to the literature on the effects of financial liberalisation on economic growth, which provides contradictory views. For example, Stulz (1999) argues that financial liberalisation increases level of investment by allowing risk diversification and lowering down agency costs. Ayhan Kose et al. (2009) find a clear and robust association between de-jure measures of financial openness and total factor productivity growth for a sample of 67 countries over the period 1966-2005. However, they find less clear evidence for the effect of de-facto measures of financial openness on TFP growth ${ }^{1}$. Similarly, Bekaert et al. (2011), dividing growth into capital stock growth and total factor productivity growth find a positive impact of financial openness on both channels of growth. On the contrary, Caprio et al. (2005) show that the liberalisation of the financial sector is followed by instability in the financial sector that causes economic growth to fall. Jarrow (2014) shows that the problems in financial markets lead to contraction of economic growth through channels of credit risk.

Crotty (2009) finds radical financial deregulation along with the New Financial Architecture $(\mathrm{NFA})^{2}$ - that is based on very weak theoretical foundations- responsible for the 2007-08 financial crisis. He concludes that the biggest reason for the recent crisis is the emergence of financial boom following the progressive deregulation along with successive bailouts of the financial institutions with the label of "too big to fail". Crotty (2009) further notes that since the NFA defines less

\footnotetext{
${ }^{1}$ Ayhan Kose et al. (2009) explain de-jure measure of capital account openness as no constraints on capital account transactions and de-facto measured as stock to foreign assets and liabilities to GDP ratio.

${ }^{2}$ New Financial Architecture refers to the integration of modern day financial markets with the era's light government regulation.
} 
regulations for commercial banks, even lesser for investment banks and hardly any for the "shadow banking system'-hedge and private equity funds and bank-created Special Investment Vehicles (SIVs), these developments have caused a remarkable increase in complex, opaque and illiquid financial assets, which have given rise to system wide leverage. Similarly, Grant (2010) also finds the roots of the recent financial crisis in the recent Financial Services Modernization Act of 1999 in the $\mathrm{USA}^{3}$.

Our study advances the literature that examines the impact of financial liberalisation policies on finance-growth relationship. Though the post-crisis literature counts the lax regulatory environment to be liable for the failure of the financial sector (Acharya and Richardson, 2009, Sinha et al., 2012, Crotty, 2009), it lacks the systematic and rigorous empirical analysis ${ }^{4}$. Our study fills this gap by analysing the impact of financial liberalisation on finance-growth relationship by employing a multiplicative interaction model with a panel data where we take into account the interactions between the alternative measures of finnanical development and financial liberalisation.

Our goal is similar to Arestis (2006) and Demetriades and Rousseau's (2011) work ${ }^{5}$, but it improves the analysis in following counts. First, the scope of our empirical model is wider than Demetriades and Rousseau's (2011) work. Our model explicitly takes into account the interactions between financial development and our measure of financial liberalisation. Second, our financial development measure is more comprehensive as it is an index of financial development (FD) using principal component analysis (PCA) of six standard measures of financial development. Third, we look into the interaction effect of each of the disaggregated measures of financial liberalisation to find out which component is more important than others. Finally, on mehtodology, we take into account the issues of parameter heterogeneity, outliers, omitted variables and endogeneity in growth equations.

We use a panel data of 88 countries over the period 1973-2005 to explore this conditional effect employing dynamic panel data analysis. Our results show the interactions between financial sector development and its liberalisation to be important for growth, with financial development

\footnotetext{
${ }^{3}$ This act called an end to the decades long regulations of the financial sector that were in place since the great depression of 1930s

${ }^{4} \mathrm{Few}$ exceptions, as discussed in the Introduction, are Arestis (2006) and Demetriades and Rousseau's (2011).

${ }^{5}$ Demetriades and Rousseau (2011) examines the impact of no banking supervision taking value 0 when there is no banking supervision and +3 when banking supervision is at its best using simple ordinary least squares (OLS) on the relationship between finance and growth. Whereas, Arestis (2006) provide a theoretical account related to the link between finance and growth in the presence of the policies of financial liberalisation. This study differs from both in terms of scope and technique.
} 
having negative effects on growth for high levels of liberalisation. Our findings suggest that the impact of financial development varies both with the overall level of financial liberalisation and when there is change in its components.

Our study is valuable as it provides evidence in support of the exisitng literature that suggests "excessive financial liberalisation" to be the main cause for almost every channels through which financial sector may loose its desired positive impact on the real economy. For example, first, the lessening impact of finance on growth may arise from the excessive financial deepening as a result of financial liberalisation. Excessive financial deepening in the form of credit expansion results in credit boom and bust cycles, which weaken the banking structure and create inflationary pressures $^{6}$. Second, financial crisis and the collapse of finance-growth relationship could be caused by the excessive risk taking behaviour of financial institutions (Móczár, 2010), which arises under the liberalised financial system (Diaz-Alejandro, 1985, Hellmann and Murdock, 1995, Easterly et al., 2001). Third, the ambiguity of the effect of financial liberalisation on private saving arises because of the ambiguities in the relationship between interest rates and savings and also due to the nature of the financial liberalisation process that also involves reversals. Bandiera et al. (2000) show that financial liberalisation leads to a fall in savings, contrary to the belief that the saving rate rises because of financial liberalisation ${ }^{7}$. Fourth, the risky investment behaviour as a result of financial liberalisation and existence of unstable financial structure (Grabel, 1995).

The structure of our paper is as follows: Section 2 discusses the data and econometric methods used in this study. Section 3 provides the main results, with robustness analysis in Section 4. Section 5 concludes.

\section{Data and Methodology}

\subsection{Data}

Our dynamic panel analysis examines five year averages of growth in 88 countries over 19732005 (see table 11 in the Appendix for the list of countries). As usual, five year averages are used to control for business cycle effects ${ }^{8}$. Data availability, specifically for financial development

\footnotetext{
${ }^{6}$ see Rousseau and Wachtel (2011) for further debate.

${ }^{7}$ Jappelli and Pagano (2000) provided similar findings for national savings and growth in OECD countries.

${ }^{8}$ Five year averages are calculated over the period 1973-1977, 1978-1982, 1983-1987, 1988-1992, 1993-1997, and 1998-2005. The observation of 1973 is used as a proxy of initial per capita real GDPfor first average over the period
} 
and financial sector liberalisation, dictates the countries selected and time period studied. Our dependent variable is Economic growth measured by growth rate of GDP per capita. In addition to financial development and financial liberalisation variables, we use explanatory variables that are common in empirical growth literature; these are Initial level of (log) real GDP per capita to control for convergence and average years of secondary schooling to represent human capital, investment growth as a measure of physical capital accumulation, exports and imports as share of GDP as a measure of openness, government expenditure as share of GDP as a measure of government size, and log of one plus consumer price index as a measure of inflation. The panel of countries has diverse mix: 22 developed countries, 12 emerging Asian economies, 17 Latin American economies, 12 countries from sub-Saharan Africa, 18 transitional economies, 7 from Middle East and North Africa.

\subsubsection{Measure of Financial Development}

A good financial development indicator should include information on different aspects of financial system such as depth, access, efficiency and stability for both financial institutions and markets. It should also provide information about the ability of the financial system to channel funds from depositors to investors (Ang and McKibbin, 2007). In order to capture as many aspects of financial development as possible, we use principal component analysis (PCA) on frequently used banking sector indicators ${ }^{9}$ of financial development to get new summary aggregate index. Following the previous studies covering the data since 1970s for financial development (e.g., Tressel and Detragiache (2008)) we choose not to use stock market indices due to their lack of data avaialability.

The use of PCA for the aggregate index of financial development is gaining popularity in growth finance literature to construct a summary index of financial development and other dimensions of financial systems (Huang, 2011, Ang and McKibbin, 2007). Methodologically, the PCA produces an orthogonal summary index using $\mathrm{N}$ number of different indicators that are highly correlated. These principle components theoretically can capture the highest amount of variance among different indicators, capturing different dimensions of the dataset.

Our PCA draws information from six financial development indicators in log form: Private 1973-1977.

${ }^{9}$ The data for all indicators are taken from the World Bank's Financial Structure and Economic Development Database (2008). 
credit/GDP ratio (PVT/Y), Liquid Liabilities/GDP ratio (LL/Y), Bank assets to deposit money bank assets and central bank assets (BA/BCBA), Deposit money banks assets/ GDP ratio (DBA/Y), Central bank assets to GDP ratio (CBA/Y), and Bank credit/ bank deposit ratio (BC/BD). Generally, studies use M2/ GDP ratio or private credit/ GDP ratio as measures of financial development. However, as Ang and McKibbin (2007) argue that these measures only show the extent of transaction services provided by the financial system rather than their ability to channelize funds, we resort to using the six indicators mentioned above. These measures of financial development are usually strongly correlated (Ang and McKibbin, 2007), which validates the use of a single representative index for the measure of financial development ${ }^{10}$.

We perform the PCA analysis over the years for our group of countries on our representative indexes of financial development ${ }^{11}$ to capture the impact of transition in the financial system across the countries over time. Our summary index measures important dynamics of the changes in the financial development due to the coverage of the data set.

Table 1: Principal component analysis for financial development index for the year 1973

\begin{tabular}{lcccccc}
\hline \hline & PCA 1 & PCA 2 & PCA 3 & PCA 4 & PCA 5 & PCA 6 \\
\hline Eigenvalues & 3.23756 & 1.62338 & .756813 & .291184 & .0728865 & .0181775 \\
\% of variance & 0.5396 & 0.2706 & 0.1261 & 0.0485 & 0.0121 & 0.0030 \\
Cumulative\% & 0.5396 & 0.8102 & 0.9363 & 0.9848 & 0.9970 & 1.0000 \\
\hline Variable & Vector 1 & Vector 2 & Vector 3 & Vector 4 & Vector 5 & Vector 6 \\
\hline LL/Y & 0.4688 & 0.3425 & -0.2591 & -0.1435 & 0.7490 & 0.1193 \\
BA/BCBA & 0.3937 & -0.4045 & -0.2712 & 0.7796 & -0.0054 & -0.0025 \\
PVT/Y & 0.5385 & 0.1035 & 0.1670 & -0.1642 & -0.2359 & -0.7673 \\
CBA/Y & -0.0940 & 0.6521 & 0.5004 & 0.5602 & 0.0412 & -0.0017 \\
DBA/Y & 0.5233 & 0.2202 & 0.0204 & -0.1448 & -0.5445 & 0.5998 \\
BC/BD & 0.2292 & -0.4843 & 0.7620 & -0.0993 & 0.2919 & 0.1929 \\
\hline \hline
\end{tabular}

${ }^{1} \mathrm{LL} / \mathrm{Y}=\mathrm{Log}$ of Liquid Liabilities to GDP Ratio

${ }^{2} \mathrm{BA} / \mathrm{BCBA}=\log$ of Deposits money bank assets to deposit money bank assets and central bank

${ }^{3} \mathrm{PVT} / \mathrm{Y}=\mathrm{Log}$ of Bank private credit to GDP (\%)

${ }^{4} \mathrm{CBA} / \mathrm{Y}=\mathrm{Log}$ of Central bank assets to GDP $(\%)$

${ }^{5} \mathrm{DBA} / \mathrm{Y}=\mathrm{Log}$ of Deposits money bank assets to GDP $(\%)$

${ }^{6} \mathrm{BC} / \mathrm{BD}=\mathrm{Log}$ of bank credit to bank deposit

\footnotetext{
${ }^{10}$ Table 14 in the Appendix shows correlation matrix for the components of financial development. With only few exceptions, all variables are significantly correlated with each other with sufficiently large magnitudes.

${ }^{11}$ The percent variance for all principal components-six in this case- for all years from 1973-2005 and the results for the first vector corresponding to the first component of principal component analysis are available upon request.
} 
For the purpose of illustration we present results for a specific year, 1973, obtained from PCA. Table 1 displays the results obtained from the PCA analysis for the year 1973. The eigenvalues indicated in the table explains about $53.96 \%$ of the standardised variance, the second principal component explains $27.06 \%$, the third explains $12.61 \%$, the fourth $4.8 \%$, the fifth $1.21 \%$ and the last principal component accounts for $0.3 \%$. From the given amount of variation explained by principal components, we observe that the first component that explains the most of the variation is the best measure of financial development. By using the weights given by the first eigenvector the first principal component is computed as a linear combination of the six measures of financial development. The individual contributions of LL/Y, BA/BCBA, PVT/Y, CBA/Y, DBA/Y, and BC/BD to the standardised variance of the first principal component comes out to be around ${ }^{12} 22.76 \%$, $19.11 \%, 26.14 \%,-4.5 \%, 25.41 \%$, and $11.13 \%$ respectively. We use these individual contributions as the basis of weighting to develop our financial development index.

\subsubsection{Measure for Financial Liberalisation}

To measure overall changes in the policies of liberalisation in our sample countries, we use an index developed by Abiad et al. (2008) that measures overall change of level of liberalisation in a sample of 91 countries. This is the most updated data set available that takes into account the overall level of financial liberalisation in different countries. Compared to earlier databases by Edison and Warnock (2003) and Kaminsky and Schmukler (2008) this data set covers wider number of countries and provides graded index for more dimensions of financial reforms. Recently many studies have used this data set to evaluate the impacts of financial reforms on the financial development (Demetriades and Rousseau, 2011, Tressel and Detragiache, 2008).

Abiad et al. (2008) provide data on aggregated index of financial reforms for 91 countries over the period 1973-2005, capturing seven major dimensions of reform. These are credit controls and reserve requirements, interest rate controls, entry barriers, state ownership, policies on securities markets, banking regulations and restrictions on capital account. Six out of these seven components are coded in such a way that higher value of these dimensions on the scale of 0-3 shows the higher level of liberalisation.

However, only "Banking supervision" component is coded in reverse order, which shows that the higher the level of banking supervision the greater is the extent of financial reforms. This

\footnotetext{
${ }^{12}$ Figures are rounded off to the second decimal place.
} 
weakness of the index can be addressed by reversing the banking supervision component and recalculating the index, which would not change the empirical results as we shall observe in section 4 on "further robustness".

The aggregated index along with sub indexes is constructed after assigning raw score to each dimension and normalizing it to $0-3$ scale. On this scale fully liberalised takes the value of 3 , partially liberalised takes the value of 2 , partially repressed takes the value of 1 and fully repressed takes the value of 0 . The dimensions of the dataset comprise many important sub-dimensions that covers further important aspects of the financial reforms brought in those countries ${ }^{13}$.

These seven aspects of financial liberalisation are aggregated to calculate 'a single liberalisation index' that takes values from 0 to 21 as each dimension values between 0 and 3 . The assigned values for the different dimensions of financial reforms are further used to construct an aggregated normalised index ranging between ' 0 ' and ' 1 ' with equal weights to all dimensions. Higher value on index means the country is more liberal. Table 15 in the Appendix shows that all the sub-indices of financial reform index are positively and significantly correlated. This implies that the countries where the emphasis is say for example on the directed credit, they may also have the emphasis on the other components such as credit ceilings, interest rate controls, etc.

\subsection{Summary Statistics and Correlations}

Table 13 in the Appendix provides summary statistics for variables used. The range of the data for different variables in table 13 shows a wide variation among the values of the variables. For example, GDP per capita growth ranges from $-45 \%$ to around $25 \%$. Financial liberalisation index is normalised and ranges between zero and one. We also observe a wide variation in the measures of financial development. Private credit/ GDP ratio, the most widely used measure of financial development, varies between $3.94 \%$ for Uganda to $146.81 \%$ for Hong Kong. The same pattern is observed for other financial development indicators. Table 16 shows correlation results where we observe positive and significant correlation between financial development and financial reform index.

Table 2 shows frequency histogram of the liberalisation index for the period 1973-2005. We divide countries in five different groups based on the average level of liberalisation in the countries

\footnotetext{
${ }^{13}$ For detailed explanation of the index formation along with their sub-dimensions and coding, please refer Abiad et al. (2008).
} 
over the period of 1973-2005. Not surprisingly, we observe that the developed countries tend to have more liberalised financial structure than the developing countries. The countries that stand out as the most liberal are United States, Netherlands, and Switzerland, while Ethiopia and China are the least financially liberal economy in our sample. The most interesting to note that the countries that have been hit the most during 2007-08 financial crisis and some of them are still facing looming threats of economic recession are amongst the most financial liberalised economy. For instance following the recession in the U.S., eurozone crisis since early 2009 has affected the financial structures of many central and eastern European economies.

Table 2: Financial Liberalisation Index

\begin{tabular}{lllll}
\hline \hline 5th Quintile & 4th Quintile & 3rd Quintile & 2nd Quintile & 1st Quintile \\
$0.71-1.00$ & $0.55-0.71$ & $0.44-0.55$ & $0.30-0.44$ & $0-0.30$ \\
\hline Belgium & Australia & Albania & Colombia & Algeria \\
Canada & Bulgaria & Argentina & Dominican Rep. & Bangladesh \\
Denmark & Chile & Austria & El Salvador & Brazil \\
Estonia & Czech Rep. & Azerbaijan & Guatemala & Cameroon \\
Georgia & Finland & Belarus & Indonesia & China \\
Germany & France & Bolivia & Jamaica & Costa Rica \\
Hong Kong & Italy & Greece & Kenya & Ecuador \\
Hungary & Japan & Israel & Madagascar & Egypt \\
Ireland & Jordan & Kazakhstan & Morocco & Ethiopia \\
Latvia & Kyrgyz Rep. & Korea & Nicaragua & Ghana \\
Lithuania & Malaysia & Mexico & Peru & India \\
Netherlands & New Zealand & Nigeria & Senegal & Mozambique \\
Singapore & Norway & Paraguay & Sri Lanka & Nepal \\
Spain & Poland & Philippines & Thailand & Pakistan \\
Sweden & Romania & Portugal & Tunisia & Tanzania \\
Switzerland & Russia & Ukraine & Turkey & Uzbekistan \\
United Kingdom & South Africa & Uruguay & Uganda & Vietnam \\
United States & & Venezuela & Zimbabwe & \\
\hline \hline
\end{tabular}

Source: Abiad et al. (2008)

The countries are divided in 5 quintile on the basis of the level of liberalisation. The least liberal economies on the scale between 0 and 1 lie in the first quintile and the most liberal economies lie in the 5th quintile.

A cursory look at the data arranged in Tables 3-5 shows us some interesting relationship even before embarking on rigorous analysis: $(i)$ the strong association between finanical development and growth; (ii) the strong association between financial liberalisation and financial development; but (iii) no clear relation betwen financial liberalisation and growth. Table 3 organises the countries in the data set in a matrix, grouping them by quintiles according to the average level of per capita GDP growth rate in those countries and the average level of financial development defined as private credit/ GDP ratio (PVT/Y). Most of our sample countries lie on the diagonal or near the 
Table 3: GDP Per Capita Growth and Financial Development

\begin{tabular}{|c|c|c|c|c|c|c|}
\hline \multicolumn{7}{|c|}{$\begin{array}{l}\text { GDP Per Capita Growth Rate } \\
\text { (Decreasing } \rightarrow \text { ) }\end{array}$} \\
\hline & & 5th Quint & 4th Quint & 3rd Quint & 2nd Quint & 1st Quint \\
\hline \multirow{5}{*}{$\begin{array}{l}\text { FD } \\
\text { (Decreasing } \downarrow \text { ) }\end{array}$} & 5th Quint & $\begin{array}{l}\text { China } \\
\text { Ireland } \\
\text { Malaysia } \\
\text { Singapore } \\
\text { Thailand }\end{array}$ & $\begin{array}{c}\text { Austria } \\
\text { United Kingdom } \\
\text { Italy } \\
\text { Jordan } \\
\text { Japan } \\
\text { Portugal } \\
\text { Spain }\end{array}$ & $\begin{array}{l}\text { Canada } \\
\text { France } \\
\text { Germnay } \\
\text { Netherlands }\end{array}$ & Switzerland & - \\
\hline & 4th Quint & $\begin{array}{c}\text { Chile } \\
\text { Korea } \\
\text { Norway } \\
\text { Tunisia } \\
\text { Vietnam }\end{array}$ & $\begin{array}{c}\text { Finland } \\
\text { United States }\end{array}$ & $\begin{array}{c}\text { Australia } \\
\text { Belgium } \\
\text { Denmark } \\
\text { Greece } \\
\text { Israel } \\
\text { Sweden }\end{array}$ & $\begin{array}{l}\text { Czech Republic } \\
\text { New Zealand }\end{array}$ & South Africa \\
\hline & 3rd Quint & $\begin{array}{l}\text { Egypt } \\
\text { Estonia } \\
\text { Indonesia } \\
\text { Poland }\end{array}$ & $\begin{array}{c}\text { Bulgaria } \\
\text { Bangladesh } \\
\text { Oominican Republic } \\
\text { Hungry } \\
\text { Morocco }\end{array}$ & $\begin{array}{l}\text { Brazil } \\
\text { Columbia }\end{array}$ & $\begin{array}{c}\text { Algeria } \\
\text { El Salvador Republic } \\
\text { Phillipines } \\
\text { Uruguay }\end{array}$ & $\begin{array}{l}\text { Bolivia } \\
\text { Jamaica } \\
\text { Nicaragua } \\
\text { Senegal }\end{array}$ \\
\hline & 2nd Quint & $\begin{array}{l}\text { Latvia } \\
\text { India } \\
\text { Sri Lanka }\end{array}$ & $\begin{array}{l}\text { Pakistan } \\
\text { Turkey }\end{array}$ & Costa Rica & $\begin{array}{l}\text { Argentina } \\
\text { Cameroon } \\
\text { Ecuador } \\
\text { Guatemala } \\
\text { Lithuania } \\
\text { Mexico } \\
\text { Nepal } \\
\text { Paraguay }\end{array}$ & $\begin{array}{c}\text { Keynea } \\
\text { Madagascar } \\
\text { Venezuela }\end{array}$ \\
\hline & 1st Quint & - & $\begin{array}{l}\text { Belarus } \\
\text { Uganda }\end{array}$ & $\begin{array}{c}\text { Albania } \\
\text { Kazakhstan } \\
\text { Mozambique }\end{array}$ & $\begin{array}{l}\text { Nigeria } \\
\text { Romania } \\
\text { Tanzania }\end{array}$ & $\begin{array}{c}\text { Azerbaijan } \\
\text { Ethiopia } \\
\text { Georgia } \\
\text { Kyrgyz Republic } \\
\text { Peru } \\
\text { Russia } \\
\text { Ukrain } \\
\text { Zimbabwe }\end{array}$ \\
\hline
\end{tabular}

\footnotetext{
${ }^{1}$ Source: Abiad et al. (2008) \& World Bank's Financial Structure and Economic Development Database (2008)

${ }^{2}$ The financial development indicator is the average level of Prviate Credit/GDP ratio in sample countries. GDP per capita growth is the average over the period.
}

diagonal that shows a well established strong positive association between financial development and economic growth. The surprising fact, on the other hand, is that despite the high level of financial development-mainly as a result of high level of financial liberalisation- many developed countries have recently experienced recession, which raises questions about the established link between financial development and growth in the presence of liberalised financial systems.

Table 4 shows another matrix that arranges countries in groups in quintiles on the basis of average level of financial liberalisation and average level of financial development in our sample countries. The table shows that most of the financially developed countries have the most lib- 
Table 4: Financial Liberalisation and Financial Development

\begin{tabular}{|c|c|c|c|c|c|c|}
\hline \multicolumn{7}{|c|}{$\begin{array}{l}\text { Financial reforms } \\
(\text { Decreasing } \rightarrow \text { ) }\end{array}$} \\
\hline & & 5th Quint & 4th Quint & 3rd Quint & 2nd Quint & 1st Quint \\
\hline \multirow{5}{*}{$\begin{array}{l}\text { FD } \\
\text { (Decreasing } \downarrow \text { ) }\end{array}$} & 5th Quint & $\begin{array}{l}\text { United Kingdom } \\
\text { Canada } \\
\text { Germany } \\
\text { Ireland } \\
\text { Netherlands } \\
\text { Singapore } \\
\text { Spain } \\
\text { Switzerland }\end{array}$ & $\begin{array}{l}\text { France } \\
\text { Italy } \\
\text { Japan } \\
\text { Jordan } \\
\text { Malysia }\end{array}$ & $\begin{array}{l}\text { Austria } \\
\text { Portugal }\end{array}$ & Thailand & China \\
\hline & 4th Quint & $\begin{array}{c}\text { Belgium } \\
\text { Denmark } \\
\text { Sweden } \\
\text { United States }\end{array}$ & $\begin{array}{c}\text { Australia } \\
\text { Chile } \\
\text { Czech Republic } \\
\text { New Zealand } \\
\text { Norway } \\
\text { South Africa }\end{array}$ & $\begin{array}{l}\text { Greece } \\
\text { Israel } \\
\text { Korea }\end{array}$ & Tunisia & Vietnam \\
\hline & 3rd Quint & $\begin{array}{l}\text { Estonia } \\
\text { Hungary }\end{array}$ & $\begin{array}{l}\text { Bulgaria } \\
\text { Poland }\end{array}$ & $\begin{array}{l}\text { Bolivia } \\
\text { Philippines I } \\
\text { Uruguay }\end{array}$ & $\begin{array}{c}\text { Columbia } \\
\text { Dominican Republic } \\
\text { El Salvador } \\
\text { Indonesia } \\
\text { Jamaica } \\
\text { Nicaragua } \\
\text { Senegal }\end{array}$ & $\begin{array}{c}\text { Algeriaa } \\
\text { Bangladesh } \\
\text { Brazil } \\
\text { Egypt }\end{array}$ \\
\hline & 2nd Quint & $\begin{array}{l}\text { Latvia } \\
\text { Lithuania }\end{array}$ & - & $\begin{array}{l}\text { Argentina } \\
\text { Mexico } \\
\text { Paraguay } \\
\text { Venezuela }\end{array}$ & $\begin{array}{c}\text { Guatemala } \\
\text { Kenya } \\
\text { Madagascar } \\
\text { Sri Lanka } \\
\text { Turkey }\end{array}$ & $\begin{array}{c}\text { Cameroon } \\
\text { Costa Rica } \\
\text { Ecuador } \\
\text { India } \\
\text { Nepal } \\
\text { Pakistan }\end{array}$ \\
\hline & 1st Quint & Georgia & $\begin{array}{l}\text { Romania } \\
\text { Russia }\end{array}$ & $\begin{array}{l}\text { Albania } \\
\text { Azerbaijan } \\
\text { Nigeria } \\
\text { Ukraine } \\
\end{array}$ & $\begin{array}{c}\text { Peru } \\
\text { Uganda } \\
\text { Zimbabwe } \\
\text { Tanzania } \\
\end{array}$ & $\begin{array}{c}\text { Ethiopia } \\
\text { Ghana } \\
\text { Mazambique }\end{array}$ \\
\hline
\end{tabular}

\footnotetext{
${ }^{1}$ Source:Abiad et al. (2008) \& World Bank's Financial Structure and Economic Development Database (2008).

${ }^{2}$ The financial development indicator is the average of Private Credit/GDP ratio. Financial liberalisation index is the average of the indexes: credit controls and reserve requirements, interest rate liberalisation, entry barriers, restrictions on capital account, privatization of the financial sector, and banking sector supervision.
}

eralised financial structures. Here also the majority of the countries lie near the diagonal or on the diagonal that also depicts a fairly strong positive correlation between the countries' level of financial liberalisation and the level of financial development.

This suggests that there is an indirect relationship between financial liberalisation and growth through positive impact on financial development that is directly associated with GDP per capita growth rate. To inquire further, we investigate how financial liberalisation and economic growth are interrelated directly. In the ex-post crisis literature the investigation about the association between financial liberalisation and economic growth rate has received special attention both from policy 
Table 5: GDP Per Capita Growth and Financial Liberalisation Index

\begin{tabular}{|c|c|c|c|c|c|}
\hline \multicolumn{6}{|c|}{$\begin{array}{l}\text { GDP Per Capita Growth Rate } \\
\text { (Decreasing } \rightarrow \text { ) }\end{array}$} \\
\hline & 5th Quint & 4th Quint & 3rd Quint & 2nd Quint & 1st Quint \\
\hline \multirow{5}{*}{$\begin{array}{l}\text { FL } \\
\text { (Decreasing } \downarrow \text { ) }\end{array}$} & $\begin{array}{c}\text { Estonia } \\
\text { Hong Kong } \\
\text { Ireland } \\
\text { Latvia } \\
\text { Singapore }\end{array}$ & $\begin{array}{c}\text { United Kingdom } \\
\text { Hungry } \\
\text { Spain } \\
\text { United States }\end{array}$ & $\begin{array}{l}\text { Belgium } \\
\text { Canada } \\
\text { Denmark } \\
\text { Germany } \\
\text { Netherlands } \\
\text { Sweden }\end{array}$ & $\begin{array}{c}\text { Lithuania } \\
\text { Switzerland }\end{array}$ & Gerogia \\
\hline & $\begin{array}{l}\text { Chile } \\
\text { Malaysia } \\
\text { Norway } \\
\text { Poland }\end{array}$ & $\begin{array}{l}\text { Bulgaria } \\
\text { Italy } \\
\text { Finland } \\
\text { Japan } \\
\text { Jordan }\end{array}$ & $\begin{array}{l}\text { Australia } \\
\text { France }\end{array}$ & $\begin{array}{c}\text { Czech Republic } \\
\text { New Zealand } \\
\text { Romania }\end{array}$ & $\begin{array}{l}\text { Kyrgyz Republic } \\
\text { Russia } \\
\text { South Africa }\end{array}$ \\
\hline & Korea & $\begin{array}{l}\text { Austria } \\
\text { Belarus } \\
\text { Portugal }\end{array}$ & $\begin{array}{c}\text { Albania } \\
\text { Greece } \\
\text { Israel } \\
\text { Kazakhstan }\end{array}$ & $\begin{array}{l}\text { Argentina } \\
\text { Mexico } \\
\text { Nigeria } \\
\text { Paraguay } \\
\text { Phillipines } \\
\text { Uruguay }\end{array}$ & $\begin{array}{c}\text { Azerbaijan } \\
\text { Bolivia } \\
\text { Ukraine } \\
\text { Venezuela }\end{array}$ \\
\hline & $\begin{array}{l}\text { Indonesia } \\
\text { Sri Lanka } \\
\text { Thailand } \\
\text { Tunisia }\end{array}$ & $\begin{array}{c}\text { Dominican Republic } \\
\text { Morocco } \\
\text { Turkey } \\
\text { Uganda }\end{array}$ & Columbia & $\begin{array}{l}\text { El Salvador } \\
\text { Guatemala }\end{array}$ & $\begin{array}{c}\text { Jamaica } \\
\text { Kenya } \\
\text { Madagascar } \\
\text { Nicaragua } \\
\text { Peru } \\
\text { Senegal } \\
\text { Zimbabwe }\end{array}$ \\
\hline & $\begin{array}{l}\text { China } \\
\text { Egypt } \\
\text { India } \\
\text { Vietnam }\end{array}$ & $\begin{array}{l}\text { Bangladesh } \\
\text { Pakistan }\end{array}$ & $\begin{array}{c}\text { Brazil } \\
\text { Costa Rica } \\
\text { Mozambique }\end{array}$ & $\begin{array}{c}\text { Algeria } \\
\text { Cameroon } \\
\text { Ecuador } \\
\text { Nepal } \\
\text { Tanzania }\end{array}$ & $\begin{array}{c}\text { Ethiopia } \\
\text { Ghana } \\
\text { Uzbekistan }\end{array}$ \\
\hline
\end{tabular}

Source: Abiad et al. (2008) \& World Bank's Financial Structure and Economic Development Database (2008)

makers and academics. For this purpose in table 5 we arrange countries from our dataset in a matrix in quintiles on the basis of their average GDP per capita growth rate and average level of liberalisation. We observe that a large number of countries are off the diagonal showing weak relationship. The extreme cases include countries like China and India, two emerging economies showing the highest rate of growth rate despite the least level of financial liberalisation over our sample period. While on the one hand these countries have been able to achieve high level of financial development despite low level of financial liberalisation, and on the other hand have also been able to achieve higher growth rates.

Allen et al. (2005) recognises China's performance as an interesting case study. They argue that despite undeveloped financial sector, China has been able to grow at the fastest pace because of the available financing channels other than formal sources. Guariglia and Poncet (2008) explain 
despite negative relationship between China-specific measures of state interventionism and growth and its sources, it has been able to achieve higher growth rates because of high level of FDI. India, another emerging economy is also among the group of the countries with least financial liberalisation and highest GDP per capita. On the other extreme there are countries like Georgia, Switzerland showing the least amount of GDP per capita growth despite the highest level of financial reforms. The other major countries showing uneven relationship between level of financial reforms and GDP per capita growth include United Kingdom, United States, Canada, and New Zealand.

\subsection{Methodology}

To analyse the impact of financial sector development on economic growth via financial liberalisation, we use an econometric model of the form employed by Levine et al. (2000), Beck, Levine and Loayza (2000), Beck and Levine (2004):

$$
y_{i, t}-y_{i, t-1}=\alpha y_{i, t-1}+\beta^{\prime} X_{i, t}+\eta_{i}+\varepsilon_{i, t}
$$

Where, $y_{i, t}$ is real per capita GDP; $X_{i, t}$ shows vector of explanatory variables except initial level of per capita GDP and includes our indicators of financial liberalisation; $\eta_{i, t}$ shows country specific fixed effects and; $\varepsilon_{i}$ shows idiosyncratic error, and the subscripts $i$ and $t$ show country and time period, respectively. To measure the time specific effects, we also include time dummies.

We use one-step and two-step versions of system GMM. The system GMM deals with the endogenous components by using lag of the variables as instruments. The one-step estimators assume error term $\varepsilon_{i t}$ to be $i, i, d$, whereas, the two-step estimators allows the error term $\varepsilon_{i t}$ to be heteroscedastic. The two-step procedure in the first step assume independent error term, and in the second step relaxes the assumption by establishing variance covariance matrix using error terms from the first step.

Rousseau and Wachtel (2000) use the same technique to study the relationship between stock market, banks and economic growth. Roodman (2006) also emphasises the use of these techniques for the models with a dynamic dependent variable, which depends on its past realizations, have independent variables that are not strictly exogenous, have fixed effects, and heteroscedasticity and autocorrelation within individuals but not across them. 
According to Arellano and Bond (1991) differencing the equation 1 yield,

$$
\left(y_{i, t}-y_{i, t-1}\right)-\left(y_{i, t-1}-y_{i, t-2}\right)=\alpha\left(y_{i, t-1}-y_{i, t-2}\right)+\beta^{\prime}\left(X_{i, t}-X_{i, t-1}\right)+\left(\varepsilon_{i, t}-\varepsilon_{i, t-1}\right)
$$

The model explained in equation 2 removes the country specific effects but introduces another bias due to correlation between new error term and lagged dependent variable. With the following two assumptions explained by Arellano and Bond (1991) we can overcome this new bias.

$$
\begin{aligned}
& E\left[y_{i, t-s}\left(\varepsilon_{i, t}-\varepsilon_{i, t-1}\right)\right]=0 \text { for } s \geq 2 ; t=3, \ldots \ldots, T \\
& E\left[X_{i, t-s}\left(\varepsilon_{i, t}-\varepsilon_{i, t-1}\right)\right]=0 \text { for } s \geq 2 ; t=3, \ldots \ldots, T
\end{aligned}
$$

The first difference GMM estimators still can be misleading in the presence of persistent variables, as lagged levels of the series provide weak instruments for subsequent first differences. Therefore, we use system GMM as suggested by Arellano and Bover (1995) to deal with this problem more effectively. According to Bond et al. (2001) the system estimator is useful even for series that are persistent. We have the following stationary conditions.

$$
E\left[y_{i, t+p} \eta_{i}\right]=E\left[y_{i, t+q} \eta_{i}\right] \text { and } E\left[X_{i, t+p} \eta_{i}\right]=E\left[X_{i, t+q} \eta_{i}\right] \text { for all } \mathrm{p} \text { and } \mathrm{q}
$$

The further moment conditions are as under,

$$
\begin{aligned}
E\left[\left(y_{i, t-s}-y_{i, t-s-1}\right)\left(\eta_{i}+\varepsilon_{i, t}\right)\right] & =0 \text { for } s=1 \\
E\left[\left(X_{i, t-s}-X_{i, t-s-1}\right)\left(\eta_{i}+\varepsilon_{i, t}\right)\right] & =0 \text { for } s=1
\end{aligned}
$$

We use moment conditions given in equations 3, 4, 6 and 7 to get GMM system estimators. To check the consistency of the estimators derived from GMM we validate the assumption that the error terms do not show serial correlation and further validate the instruments. For this purpose we use Sargan test of over-identifying restriction and the second test is to check if the error term $\varepsilon_{i, t}$ is not serially correlated.

Equation (8) shows the exact specification for our model. 


$$
\begin{array}{r}
P C G_{i, t}=\beta_{1}\left(L Y_{o}\right)_{i, t}+\beta_{2} F D_{i, t}+\beta_{3} F L_{i, t}+\beta_{4}(F D * F L)_{i, t}+\beta_{5} \text { Investment }_{i, t} \\
+\beta_{6} \text { Trade Openness }_{i, t}+\beta_{7} \text { Government Size }_{i, t}+\beta_{8} \text { Inflation }_{i, t} \\
+\beta_{9} \text { Education }_{i, t}+\varepsilon_{i, t}+\eta_{i}
\end{array}
$$

where, $\mathrm{PCG}=$ Per capita growth; $\left(L Y_{o}\right)_{i, t}=$ initial value of per-capita GDP; FL= Indicator of financial liberalisation; $(F D * F L)_{i, t}=$ Interaction showing financial development at different level of financial liberalisation. Investment= growth rate of investment; trade openness= import plus export as ratio of GDP; government size $=$ government expenditure as a ratio of GDP; inflation $=\log$ of one plus consumer price index; education $=\log$ of secondary years of education; $\eta=$ country specific fixed effects and; $\varepsilon=$ idiosyncratic error.

We hypothesize $\beta_{2}>0$ and $\beta_{4}<0$, which means that individual effects of financial development is positive but the overall impact becomes less positive or negative with higher level of financial liberalisation.

Since our sample consists of a large heterogeneous group of countries over a long period of time between 1973-2005, there is a very strong likelihood of the presence of outliers in our sample. Hadi et al. (2009) argues the presence of outliers can affect the results of the regression analysis that assumes homogeneity of the data and no outliers. We use Hadi (1992) method for identifying multiple outliers to the main variables in our analysis, using 0.01 as the cut of significance level. Variety of analyses in economics literature use this method for detection and exclusion of outliers (see for instance, Rajan and Subramanian (2005))

\section{Results}

This section provides estimation results of the models used in this study. Employing onestep and two-step system GMM, unlike previous studies in finance-growth literature, we regress our model in Equation (8) that includes the measures of financial liberalisation and financial development along with their interactions in order to examine the conditional effects of financial liberalisation on the relationship between financial development and growth. We then investigate the same effects using the disaggregated components of financial liberalisation. 


\subsection{Aggregate Financial Liberalisation}

One-step system GMM is preferred in literature due to its ability to correct small sample bias (Soto et al., 2009). For the two-step system GMM we remove small sample bias with Windmeijer corrected standard errors. As noted by Roodman (2009), before applying the Windmeijer's correction researchers draw inferences from one-step system GMM. We also present first the results for one-step system GMM and then use the two-step GMM methodology by applying Windmeijer's correction. The estimation results for each model are initially shown using all observations. Then at this stage, we perform robustness analysis in two ways. First, by excluding outliers. For this purpose we follow Hadi's (1992) method of multiple variable outliers that is 'distance based method' for omitting outliers. Second, by checking if our results remain the same for alternative definitions of financial development with and without outliers. We use full set of other co-variates in all regressions.

Table 6 displays the results for all observations in Panel A and the results without outliers in Panel B. Our main results are shown in the first two columns based on our main finanical development variable constructed by PCA. The coefficient of financial development has expected positive signs with significance at $1 \%$ in both columns for PCA with or without outliers. The coefficient of financial liberalization is insignificant for all observations. But when we exclude outliers, we observe negative significant coefficient for financial liberalization. This is contrary to "financial liberalisation" hyposthesis. However, in order to verify that our results are not particularly driven by PCA measure, we also ran the same set of regressions using two variables that are most frequently used in the finance-growth literature, i.e., private-credit to GDP ratio and liquid-liability ratio. Their resutls are shown in middle two columns and last two columns respectively. The coefficient of financial development has expected positive signs with significance at $1 \%$ in both columns for all financial development indicators with or without outliers. But financial liberalization turns out to have insignificant coefficients for both private-credit to GDP ratio and liquid liability ratio for estimations with and without outliers. This suggests that financial development has direct positive impact on economic growth, while financial liberalization doesn't have any robust direct relationship with growth.

Of most interest for our study, however, is the negative interaction between financial development and financial liberalisation, indicating that the growth effect of financial development is, as hypothesised in Section 2, conditional on the level of financial liberalisation. In the case of our 
Table 6: Financial Liberalisation, Financial Development and Economic Growth

\begin{tabular}{|c|c|c|c|c|c|c|}
\hline \multicolumn{7}{|c|}{ Panel A: All observations (Dependent Variable: GDP Per Capita Growth Rate) } \\
\hline & \multicolumn{2}{|c|}{$(\mathrm{PCA})$} & \multicolumn{2}{|c|}{$(\mathrm{PVT} / \mathrm{Y})$} & \multicolumn{2}{|c|}{ (LLR) } \\
\hline & $(1)$ & $(2)$ & (3) & $(4)$ & $(5)$ & $(6)$ \\
\hline & One-step & Two-step & One-step & Two-step & One-step & Two-step \\
\hline & SGMM & SGMM & SGMM & SGMM & SGMM & SGMM \\
\hline \multirow[t]{2}{*}{ Financial Development (FD) } & 2.688 & 2.549 & 0.093 & 0.082 & 0.070 & 0.067 \\
\hline & {$[0.648]^{* * *}$} & {$[0.662]^{* * *}$} & {$[0.028]^{* * *}$} & {$[0.032]^{* *}$} & {$[0.024]^{* * *}$} & {$[0.023]^{* * *}$} \\
\hline \multicolumn{2}{|c|}{ Financial Liberalization (FL) 0.877} & 1.454 & 2.085 & 1.862 & 1.797 & 1.405 \\
\hline & [1.940] & {$[1.890]$} & {$[2.121]$} & {$[2.001]$} & [2.311] & {$[2.131]$} \\
\hline \multirow[t]{2}{*}{$\mathrm{FD} * \mathrm{FL}$} & -2.804 & -2.592 & -0.102 & -0.088 & -0.081 & -0.080 \\
\hline & {$[0.809]^{* * *}$} & {$[0.796]^{* * *}$} & {$[\mathbf{0 . 0 3 1}]^{* * *}$} & {$[\mathbf{0 . 0 3 8}]^{* *}$} & {$[\mathbf{0 . 0 2 8}]^{* * *}$} & {$[0.025]^{* * * *}$} \\
\hline \multirow[t]{2}{*}{ Log of initial GDPPC } & -0.568 & -0.553 & 0.180 & 0.241 & 0.271 & 0.301 \\
\hline & {$[0.389]$} & {$[0.435]$} & {$[0.362]$} & {$[0.368]$} & {$[0.372]$} & {$[0.455]$} \\
\hline \multirow[t]{2}{*}{ Investment } & 0.249 & 0.234 & 0.298 & 0.286 & 0.303 & 0.279 \\
\hline & {$[0.044] * * *$} & {$[0.049]^{* * *}$} & {$[0.045]^{* * *}$} & {$[0.054]^{* * *}$} & {$[0.046]^{* * *}$} & {$[0.049]^{* * *}$} \\
\hline \multirow[t]{2}{*}{ Trade openness } & -0.011 & -0.006 & 0.002 & 0.002 & 0.003 & 0.004 \\
\hline & {$[0.011]$} & {$[0.010]$} & {$[0.006]$} & {$[0.005]$} & {$[0.005]$} & {$[0.006]$} \\
\hline \multirow[t]{2}{*}{ Government size } & -0.121 & -0.124 & -0.136 & -0.151 & -0.161 & -0.161 \\
\hline & {$[0.079]$} & {$[0.086]$} & {$[0.094]$} & {$[0.086]^{*}$} & {$[0.093]^{*}$} & {$[0.071] * *$} \\
\hline \multirow[t]{2}{*}{ Human capital } & 1.219 & 0.833 & 0.170 & 0.045 & 0.560 & 0.603 \\
\hline & {$[0.846]$} & {$[1.030]$} & [0.709] & {$[0.906]$} & {$[0.770$} & {$[0.853]$} \\
\hline \multirow{2}{*}{ Inflation(CPI) } & 0.223 & 0.241 & 0.689 & 0.773 & 0.668 & 0.646 \\
\hline & {$[0.324]$} & {$[0.408]$} & {$[0.386]^{*}$} & {$[0.400]^{*}$} & {$[0.419]$} & [0.389] \\
\hline \multirow[t]{2}{*}{ Constant } & 6.148 & 5.513 & -3.495 & -3.864 & -3.838 & -3.593 \\
\hline & {$[3.087]^{*}$} & [3.555] & [2.306] & {$[2.720]$} & {$[2.263]^{*}$} & {$[2.800]$} \\
\hline Observations & 339 & 339 & 361 & 361 & 354 & 354 \\
\hline $\mathrm{F}$ & 9.917 & 9.286 & 11.378 & 13.285 & 10.459 & 12.223 \\
\hline Hansen p-value & 0.333 & 0.333 & 0.423 & 0.423 & 0.666 & 0.666 \\
\hline AR1 test p-value & 0.000 & 0.000 & 0.000 & 0.001 & 0.000 & 0.001 \\
\hline AR2 test $\mathrm{p}$-value & 0.667 & 0.715 & 0.623 & 0.715 & 0.795 & 0.863 \\
\hline No of countries/instruments & $76 / 66$ & $76 / 66$ & $77 / 66$ & $77 / 66$ & $77 / 66$ & $77 / 66$ \\
\hline \multicolumn{7}{|c|}{ Panel B: Without Outliers (Dependent Variable: GDP Per Capita Growth Rate) } \\
\hline & $(7)$ & $(8)$ & $(9)$ & $(10)$ & $(11)$ & $(12)$ \\
\hline \multicolumn{2}{|c|}{ Financial Development (FD) 1.795} & 1.669 & 0.066 & 0.065 & 0.042 & 0.048 \\
\hline & {$[0.401]^{* * *}$} & {$[0.504]^{* * *}$} & {$[0.019]^{* * *}$} & {$[0.022] * * *$} & {$[0.017]^{* *}$} & {$[0.028]^{*}$} \\
\hline Financial Liberalization (FL & -3.573 & -3.581 & 1.378 & 1.538 & 1.273 & 0.923 \\
\hline & {$[1.633]^{* *}$} & {$[1.455]^{* *}$} & [1.990] & {$[1.650]$} & [1.917] & {$[2.345]$} \\
\hline $\mathrm{FD} * \mathrm{FL}$ & -2.274 & -2.074 & -0.080 & -0.073 & -0.055 & -0.056 \\
\hline & {$[0.626]^{* * *}$} & {$[0.741]^{* * *}$} & {$[0.023]^{* * *}$} & {$[0.026]^{* * *}$} & {$[0.024]^{* *}$} & {$[0.038]$} \\
\hline Log of initial GDPPC & -0.102 & -0.146 & -0.082 & -0.223 & -0.189 & -0.302 \\
\hline & {$[0.370]$} & {$[0.433]$} & {$[0.395]$} & {$[0.443]$} & {$[0.375]$} & {$[0.387]$} \\
\hline Investment & 0.280 & 0.275 & 0.264 & 0.266 & 0.266 & 0.257 \\
\hline & {$[\mathbf{0 . 0 3 4}]^{* * *}$} & {$[0.041]^{* * *}$} & {$[0.039] * * *$} & {$[\mathbf{0 . 0 3 2}]^{* * *}$} & {$[0.039] * *$} & {$[0.039] * * *$} \\
\hline Trade openness & 0.015 & 0.012 & 0.019 & 0.015 & 0.017 & 0.023 \\
\hline & {$[0.008]^{*}$} & {$[0.011]$} & {$[0.009]^{* *}$} & {$[0.010]$} & {$[0.010]^{*}$} & {$[0.014]$} \\
\hline Government size & -0.012 & -0.007 & -0.041 & 0.004 & 0.003 & -0.069 \\
\hline & {$[0.063]$} & {$[0.077]$} & {$[0.064]$} & {$[0.080]$} & {$[0.060]$} & {$[0.084]$} \\
\hline Human capital & 2.247 & 2.257 & 0.431 & 0.426 & 2.122 & 0.478 \\
\hline & {$[0.821]^{* * *}$} & {$[0.905]^{* *}$} & {$[0.148]^{* * *}$} & {$[0.188]^{* *}$} & {$[0.866]^{* *}$} & {$[0.173]^{* * *}$} \\
\hline Inflation(CPI) & 0.264 & 0.270 & 0.547 & 0.333 & 0.429 & 0.486 \\
\hline & {$[0.257]$} & {$[0.326]$} & {$[0.296]^{*}$} & {$[0.400]$} & {$[0.334]$} & {$[0.432]$} \\
\hline Constant & 1.100 & 1.536 & -3.448 & -1.971 & -0.917 & -2.188 \\
\hline & [2.318] & [2.832] & [2.166] & {$[2.388$} & {$[2.744]$} & {$[2.765]$} \\
\hline Observations & 328 & 328 & 346 & 346 & 337 & 337 \\
\hline $\mathrm{F}$ & 17.995 & 16.510 & 15.499 & 16.456 & 17.757 & 13.443 \\
\hline Hansen p-value & 0.758 & 0.758 & 0.825 & 0.825 & 0.873 & 0.737 \\
\hline AR1 test p-value & 0.001 & 0.001 & 0.005 & 0.003 & 0.003 & 0.004 \\
\hline AR2 test $\mathrm{p}$-value & 0.662 & 0.641 & 0.869 & 0.762 & 0.907 & 0.932 \\
\hline No of countries/instruments & $73 / 66$ & $73 / 66$ & $75 / 66$ & $75 / 66$ & $75 / 66$ & $75 / 66$ \\
\hline
\end{tabular}

Notes: The table reports regression coefficients (significant coefficients are written bold) for one-step and two-step system GMM with their respective robust standard errors in brackets $(* \mathrm{p}<0.10$, $* * \mathrm{p}<0.05, * * * \mathrm{p}<0.01)$. All regressions include time dummies. Financial liberalisation index is taken from Abiad et al. (2008). 
main specification (results reported in models 1, 2, 7 and 8) with and without outliers, the coefficients for financial liberalisation are negative and significant at $1 \%$ level. For the specifications with other two measures of financial development (reported in models 3-6 and 9-12), its coefficients are negative and significant at $1 \%$ or $5 \%$ levels, with the exception of model 12 for which the coefficient is negative but not significant.

Taking model (7) of Table 6 as the preferred representative of these results after the exclusion of outliers using one-step system GMM, where both the coefficients are significant at $1 \%$ level, the partial derivative of GDP per capita Growh with respect to a unit increase in financial development is given by:

$$
\frac{\partial \text { GDP per capita Growh }}{\partial F D}=1.795-2.274(F L)
$$

The negative coefficient for the interaction term between financial liberalisation and financial development shows the declining impact of financial development on growth as the level of financial liberalisation increases. After certain point the net effect of financial development on growth becomes negative when financial liberalisation reaches to very high level. A threshold value for the financial liberalisation can be determined after plugging in the values for financial liberalisation index that ranges between 0 to 1 in Equation (9). We find that the values higher than 0.79 of the financial liberalisation index make the effect of financial development on economic growth negative.

There are a number of other points of interest in this table. Among these, it is notable that outliers play an important role. The removal of outliers, as appropriate, has a substantial impact on the size and significance of the variables that are our focus of interest. For example, the size of our main variables (FD and its interaction with FL) is reduced due to the exclusion of outliers, though the coefficients do not loose their significance. Human capital has positive coefficient, which gains the size and significance substantially after the removal of outliers in all specifications. Investment, as expected, is another variable that turns out to be positive and highly significant (at $1 \%$ level), and its size even increases after the exclusion of outliers. However, the coefficient of initial GDP per capita does not show any significance, although its coefficients are consistently negative for the models without outliers. Trade openness does not appear to play a robust role, with a positive significant coefficients only after removal of outliers. Government size generally shows negative 
sign without significance. Finally, inflation sometimes shows positive and signifiant coefficient, which is contrary to popular belief.

To validate the consistency of the estimates under GMM-system, we use tests introduced in (Roodman, 2006) command of xtabond2 for exogeneity. Arellano and Bond (1991) propose two approaches to tests for the exogeneity of the instruments used in GMM-system. The first test is related to the issue of serial correlation, and the second tests named as Hansen test is suggested to test for the over-identification. The test for serial correlation hypothesize no serial correlation in errors $\left(\varepsilon_{i, t}\right)$. The $\operatorname{AR}(1)$ p-values for all specifications are less than 0.01 , that suggest that there is autocorrelation in the first difference, whereas, the second order no serial correlation between errors can not be rejected as all values are greater than 0.01 .

The Stata output reports (Hansen, 1982) J statistic instead of the Sargan test when we use robust option with our GMM-system. Therefore, our results report (Hansen, 1982) J statistic that has null hypothesis that "the instruments as a group are exogenous". The reported p-values over all of our specifications has sufficiently higher p-values than 0.01 , which confirms the exogeneity of the instruments in our models and shows that the instruments are not correlated with disturbance process.

\subsection{Disaggregated components of Financial Liberalisation}

Table 7 reports the results for financial development and the seven components ${ }^{14}$ of financial liberalisation index one at a time, using our preferred method of one-step system GMM without outliers. ${ }^{15}$ All interaction terms for components of financial liberalisation with financial development are negative and except for credit control reforms all are highly significant, showing a declining impact of financial development with higher levels of financial liberalisation irrespective of its components. Most interestingly, when we use the other two measures of financial development in Table 8 and Table 9 for robustness check, we observe that these interaction effects remain the same.

All financial development indicators in all three tables (Table 7, Table 8, and Table 9) show

\footnotetext{
${ }^{14}$ These seven components include banking supervisory reforms, relaxation of entry barriers, lessening of credit controls, liberalisation of stock market, privatization, lessening interest rate controls, and capital controls.

${ }^{15}$ We have also run two-step system GMM without outliers and the results are essentially similar with different size of the coefficients, where banking supervision looses its significance although the positive sign remains intact. Also for interaction terms, only difference we observe in the case of stock market reforms which become insignificant for two-step system GMM. The results are available upon request.
} 
Table 7: Financial Liberalisation, Financial Development, and Economic Growth, one-step system GMM without Oultiers

\begin{tabular}{|c|c|c|c|c|c|c|c|}
\hline & \multicolumn{7}{|c|}{ Dependent Variable: GDP Per Capita Growth Rate } \\
\hline & $(1)$ & $(2)$ & (3) & $(4)$ & $(5)$ & $(6)$ & $(7)$ \\
\hline FD & $\mathbf{1 . 1 9 3}$ & 1.521 & $\mathbf{1 . 0 5 7}$ & 1.151 & 1.046 & 1.604 & 1.273 \\
\hline & {$[0.316]^{* * *}[$} & {$[0.388]^{* * *}$} & {$[0.632]^{*}$} & {$[0.517]^{* *}$} & {$[0.353]^{* * *}$} & {$[0.422] * * *$} & {$[0.347] * * *$} \\
\hline Banking supervision & $\begin{array}{c}0.795 \\
{[0.395]^{* *}}\end{array}$ & & & & & & \\
\hline Banking supervision*FD & $\begin{array}{c}-0.518 \\
{[0.149]^{* * * *}}\end{array}$ & & & & & & \\
\hline Entry barriers & & $\begin{array}{c}-0.342 \\
{[0.264]}\end{array}$ & & & & & \\
\hline Entry barriers*FD & & $\begin{array}{c}-0.499 \\
{[0.153]^{* * * *}}\end{array}$ & & & & & \\
\hline Credit controls & & & $\begin{array}{c}-0.718 \\
{[0.267]^{* * *}}\end{array}$ & & & & \\
\hline Credit controls*FD & & & $\begin{array}{c}-0.279 \\
{[0.224]}\end{array}$ & & & & \\
\hline Stock markets & & & & $\begin{array}{c}0.441 \\
{[0.407]}\end{array}$ & & & \\
\hline Stock markets*FD & & & & $\begin{array}{c}-0.390 \\
{[0.224]^{*}}\end{array}$ & & & \\
\hline Privatization & & & & & $\begin{array}{c}-0.247 \\
{[0.199]}\end{array}$ & & \\
\hline Privatization*FD & & & & & $\begin{array}{c}-0.454 \\
{[0.163]^{* * *}}\end{array}$ & & \\
\hline Interest rate liberalisation & & & & & & $\begin{array}{c}-0.364 \\
{[0.260]}\end{array}$ & \\
\hline Interest rate liberalisation*FD & & & & & & $\begin{array}{c}-0.541 \\
{[0.180] * * *}\end{array}$ & \\
\hline Capital controls & & & & & & & $\begin{array}{c}-0.875 \\
{[0.391]^{* *}}\end{array}$ \\
\hline Capital controls*FD & & & & & & & $\begin{array}{c}-0.397 \\
{[0.186]^{* *}}\end{array}$ \\
\hline Log of initial GDPPC & $\begin{array}{c}-0.505 \\
{[0.319]}\end{array}$ & $\begin{array}{c}-0.244 \\
{[0.346]}\end{array}$ & $\begin{array}{c}-0.216 \\
{[0.311]}\end{array}$ & $\begin{array}{c}-0.599 \\
{[0.386]}\end{array}$ & $\begin{array}{c}-0.193 \\
{[0.318]}\end{array}$ & $\begin{array}{c}-0.291 \\
{[0.358]}\end{array}$ & $\begin{array}{c}-0.434 \\
{[0.334]}\end{array}$ \\
\hline Investment & 0.269 & 0.254 & 0.280 & 0.268 & 0.284 & 0.275 & 0.292 \\
\hline & {$[0.042]^{* * * *}[$} & {$[0.038] * * *$} & {$[0.038] * * * \mid$} & {$[0.041] * * *$} & {$[0.041] * * *$} & {$[0.036] * * *$} & {$[0.039] * * *$} \\
\hline Trade openness & $\begin{array}{c}0.011 \\
{[0.010]}\end{array}$ & $\begin{array}{c}0.012 \\
{[0.008]}\end{array}$ & $\begin{array}{c}0.015 \\
{[0.010]}\end{array}$ & $\begin{array}{c}0.005 \\
{[0.010]}\end{array}$ & $\begin{array}{c}0.012 \\
{[0.008]}\end{array}$ & $\begin{array}{c}0.011 \\
{[0.007]}\end{array}$ & $\begin{array}{c}0.009 \\
{[0.007]}\end{array}$ \\
\hline Government size & $\begin{array}{c}-0.082 \\
{[0.065]}\end{array}$ & $\begin{array}{l}-0.052 \\
{[0.061]}\end{array}$ & $\begin{array}{l}-0.095 \\
{[0.072]}\end{array}$ & $\begin{array}{l}-0.006 \\
{[0.067]}\end{array}$ & $\begin{array}{l}-0.036 \\
{[0.070]}\end{array}$ & $\begin{array}{l}-0.027 \\
{[0.061]}\end{array}$ & $\begin{array}{c}0.003 \\
{[0.064]}\end{array}$ \\
\hline Inflation(CPI) & $\begin{array}{c}0.214 \\
{[0.250]}\end{array}$ & $\begin{array}{c}0.207 \\
{[0.222]}\end{array}$ & $\begin{array}{c}0.621 \\
{[0.295]^{* *}}\end{array}$ & $\begin{array}{c}0.190 \\
{[0.251]}\end{array}$ & $\begin{array}{c}0.317 \\
{[0.246]}\end{array}$ & $\begin{array}{c}0.149 \\
{[0.245]}\end{array}$ & $\begin{array}{c}0.331 \\
{[0.261]}\end{array}$ \\
\hline Human capital & $\begin{array}{c}0.676 \\
{[0.832]}\end{array}$ & $\begin{array}{c}1.478 \\
{[0.906]}\end{array}$ & $\begin{array}{c}1.593 \\
{[0.866]^{*}}\end{array}$ & $\begin{array}{c}1.613 \\
{[0.986]}\end{array}$ & $\begin{array}{c}1.461 \\
{[0.970]}\end{array}$ & $\begin{array}{c}2.080 \\
{[0.777]^{* * *}}\end{array}$ & $\begin{array}{c}2.570 \\
{[0.708]^{* * * *}}\end{array}$ \\
\hline Constant & $\begin{array}{c}3.116 \\
{[2.487]}\end{array}$ & $\begin{array}{c}1.986 \\
{[2.212]}\end{array}$ & $\begin{array}{c}0.907 \\
{[2.490]}\end{array}$ & $\begin{array}{c}2.855 \\
{[2.777]}\end{array}$ & $\begin{array}{c}0.232 \\
{[2.260]}\end{array}$ & $\begin{array}{c}1.834 \\
{[2.327]} \\
\end{array}$ & $\begin{array}{c}2.467 \\
{[2.141]} \\
\end{array}$ \\
\hline Observations & 328 & 328 & 328 & 328 & 328 & 328 & 328 \\
\hline $\mathrm{F}$ & 17.216 & 18.507 & 13.696 & 14.110 & 13.513 & 21.434 & 14.297 \\
\hline Hansen p-value & 0.482 & 0.911 & 0.891 & 0.580 & 0.855 & 0.808 & 0.774 \\
\hline AR1 test p-value & 0.000 & 0.000 & 0.001 & 0.000 & 0.001 & 0.002 & 0.001 \\
\hline AR2 test $p$-value & 0.990 & 0.890 & 0.596 & 0.874 & 0.829 & 0.436 & 0.655 \\
\hline No of countries/instruments & $73 / 66$ & $73 / 66$ & $73 / 66$ & $73 / 66$ & $73 / 66$ & $73 / 66$ & $73 / 66$ \\
\hline
\end{tabular}

The table reports regression results (significant coefficients are written bold) for one-step system GMM after excluding outliers using Hadi (1992) method and robust standard errors are in brackets. $* \mathrm{p}<0.10, * * \mathrm{p}<0.05, * * * \mathrm{p}<0.01$. Financial Development index here is obtained using PCA measures on six measures of financial development: Log of liquidity liability/GDP, log of deposit money bank assets/ deposit bank assets plus central bank assets, log of private credit/GDP, log of central bank assets/GDP, log of deposit money bank assets/ GDP, and log bank credit/bank deposit. Financial liberalisation index is taken from Abiad et al. (2008). 
Table 8: Financial Liberalisation, Financial Development, and Economic Growth, one-step system GMM with PVT/Y without outliers

\begin{tabular}{|c|c|c|c|c|c|c|c|}
\hline & \multicolumn{7}{|c|}{ Dependent Variable: GDP Per Capita Growth Rate } \\
\hline & (1) & (2) & (3) & (4) & (5) & (6) & (7) \\
\hline \multirow[t]{2}{*}{$\overline{\mathrm{FD}}$} & 0.024 & 0.051 & 0.044 & 0.058 & 0.031 & 0.057 & 0.048 \\
\hline & {$[0.013]^{*}$} & {$[0.022] * *$} & [0.031] & {$[0.030]^{*}$} & [0.020] & {$[0.020] * * *$} & {$[0.025] *$} \\
\hline \multirow[t]{2}{*}{ Banking supervision } & 0.989 & & & & & & \\
\hline & {$[0.466]^{* *}$} & & & & & & \\
\hline \multirow[t]{2}{*}{ Banking supervision*FD } & -0.011 & & & & & & \\
\hline & {$[0.004]^{* * *}$} & & & & & & \\
\hline \multirow[t]{2}{*}{ Entry barriers } & & 0.336 & & & & & \\
\hline & & $\begin{array}{l}{[0.388]} \\
-\mathbf{0 . 0 1 8}\end{array}$ & & & & & \\
\hline Entry barriers*FD & & $\begin{array}{c}-\mathbf{0 . 0 1 8} \\
{[0.008]^{* *}}\end{array}$ & & & & & \\
\hline Credit controls & & & $\begin{array}{l}-0.247 \\
{[0.493]}\end{array}$ & & & & \\
\hline Credit controls*FD & & & $\begin{array}{c}-0.017 \\
{[0.011]}\end{array}$ & & & & \\
\hline Stock markets & & & & $\begin{array}{c}1.117 \\
{[0.499]^{* *}}\end{array}$ & & & \\
\hline Stock markets*FD & & & & $\begin{array}{c}-0.021 \\
{[0.010]^{* * *}}\end{array}$ & & & \\
\hline Privatization & & & & & $\begin{array}{l}-0.016 \\
{[0.432]}\end{array}$ & & \\
\hline Privatization*FD & & & & & $\begin{array}{c}-0.017 \\
{[0.008]^{* *}}\end{array}$ & & \\
\hline Interest rate liberalisation & & & & & & $\begin{array}{c}0.122 \\
{[0.401]}\end{array}$ & \\
\hline Interest rate liberalisation*FD & & & & & & $\begin{array}{c}-0.019 \\
{[0.007]^{* * *}}\end{array}$ & \\
\hline Capital controls & & & & & & & $\begin{array}{c}-0.358 \\
{[0.486]}\end{array}$ \\
\hline Capital controls*FD & & & & & & & $\begin{array}{c}-0.016 \\
{[0.009]^{*}}\end{array}$ \\
\hline Log of initial GDPPC & $\begin{array}{l}-0.421 \\
{[0.354]}\end{array}$ & $\begin{array}{c}-0.292 \\
{[0.371]}\end{array}$ & $\begin{array}{c}-0.248 \\
{[0.393]}\end{array}$ & $\begin{array}{l}-0.563 \\
{[0.400]}\end{array}$ & $\begin{array}{c}0.049 \\
{[0.384]}\end{array}$ & $\begin{array}{c}-0.253 \\
{[0.371]}\end{array}$ & $\begin{array}{l}-0.255 \\
{[0.385]}\end{array}$ \\
\hline \multirow[t]{2}{*}{ Investment } & 0.262 & 0.240 & 0.269 & 0.247 & 0.268 & 0.251 & 0.265 \\
\hline & {$[0.044]^{* * *}$} & {$[0.041]^{* * *}$} & {$[0.041]^{* * *}$} & {$[0.041]^{* * *}$} & {$[0.040] * * *$} & $*[0.039] * * *$ & {$[0.039] * * *$} \\
\hline Trade openness & $\begin{array}{c}0.010 \\
{[0.009]}\end{array}$ & $\begin{array}{c}0.015 \\
{[0.009]}\end{array}$ & $\begin{array}{c}0.015 \\
{[0.010]}\end{array}$ & $\begin{array}{c}0.006 \\
{[0.010]}\end{array}$ & $\begin{array}{c}0.019 \\
{[0.009]^{* *}}\end{array}$ & $\begin{array}{c}0.016 \\
{[0.007]^{* *}}\end{array}$ & $\begin{array}{c}0.016 \\
{[0.009]^{*}}\end{array}$ \\
\hline Government size & $\begin{array}{c}-0.076 \\
{[0.080]}\end{array}$ & $\begin{array}{c}-0.043 \\
{[0.068]}\end{array}$ & $\begin{array}{c}-0.110 \\
{[0.066]^{*}}\end{array}$ & $\begin{array}{c}-0.071 \\
{[0.066]}\end{array}$ & $\begin{array}{c}-0.037 \\
{[0.077]}\end{array}$ & $\begin{array}{c}-0.077 \\
{[0.070]}\end{array}$ & $\begin{array}{c}-0.087 \\
{[0.070]}\end{array}$ \\
\hline Inflation (CPI) & $\begin{array}{c}0.539 \\
{[0.285]^{*}}\end{array}$ & $\begin{array}{c}0.377 \\
{[0.265]}\end{array}$ & $\begin{array}{c}0.775 \\
{[0.347]^{* *}}\end{array}$ & $\begin{array}{c}0.409 \\
{[0.259]}\end{array}$ & $\begin{array}{c}0.521 \\
{[0.334]}\end{array}$ & $\begin{array}{c}0.569 \\
{[0.296]^{*}}\end{array}$ & $\begin{array}{c}0.687 \\
{[0.271]^{* *}}\end{array}$ \\
\hline Human capital & $\begin{array}{c}0.213 \\
{[0.183]}\end{array}$ & $\begin{array}{c}0.389 \\
{[0.183]^{* *}}\end{array}$ & $\begin{array}{c}0.522 \\
{[0.212]^{* *}}\end{array}$ & $\begin{array}{c}0.424 \\
{[0.223]^{*}}\end{array}$ & $\begin{array}{c}0.301 \\
{[0.213]}\end{array}$ & $\begin{array}{c}0.400 \\
{[0.199]^{* *}}\end{array}$ & $\begin{array}{c}0.585 \\
{[0.196]^{* * * *}}\end{array}$ \\
\hline Constant & $\begin{array}{l}-0.678 \\
{[1.979]}\end{array}$ & $\begin{array}{l}-2.267 \\
{[2.166]}\end{array}$ & $\begin{array}{l}-3.170 \\
{[2.229]}\end{array}$ & $\begin{array}{l}-1.343 \\
{[2.239]}\end{array}$ & $\begin{array}{c}-4.443 \\
{[2.175]^{* *}}\end{array}$ & $\begin{array}{l}-2.727 \\
{[2.092]}\end{array}$ & $\begin{array}{l}-3.587 \\
{[2.213]}\end{array}$ \\
\hline Observations & 346 & 346 & 346 & 346 & 346 & 346 & 346 \\
\hline $\mathrm{F}$ & 14.287 & 14.410 & 12.464 & 16.384 & 14.549 & 16.165 & 13.547 \\
\hline Hansen p-value & 0.749 & 0.560 & 0.969 & 0.906 & 0.934 & 0.653 & 0.775 \\
\hline AR1 test $p$-value & 0.001 & 0.002 & 0.003 & 0.001 & 0.004 & 0.004 & 0.005 \\
\hline AR2 test $p$-value & 0.889 & 0.947 & 0.535 & 0.984 & 0.827 & 0.645 & 0.841 \\
\hline No of countries/instruments & $75 / 66$ & $75 / 66$ & $75 / 66$ & $75 / 66$ & $75 / 66$ & $75 / 66$ & $75 / 66$ \\
\hline
\end{tabular}

The table reports regression results (significant coefficients are written bold) for two-step system GMM after excluding outliers using Hadi (1992) method and robust standard errors are in brackets. $* \mathrm{p}<0.10$, $* * \mathrm{p}<0.05$, $* * * \mathrm{p}<0.01$. FD here is private credit/GDP ratio. FL index is taken from Abiad et al. (2008). 
Table 9: Financial Liberalisation, Financial Development, and Economic Growth, one-step system GMM with LLR without outliers

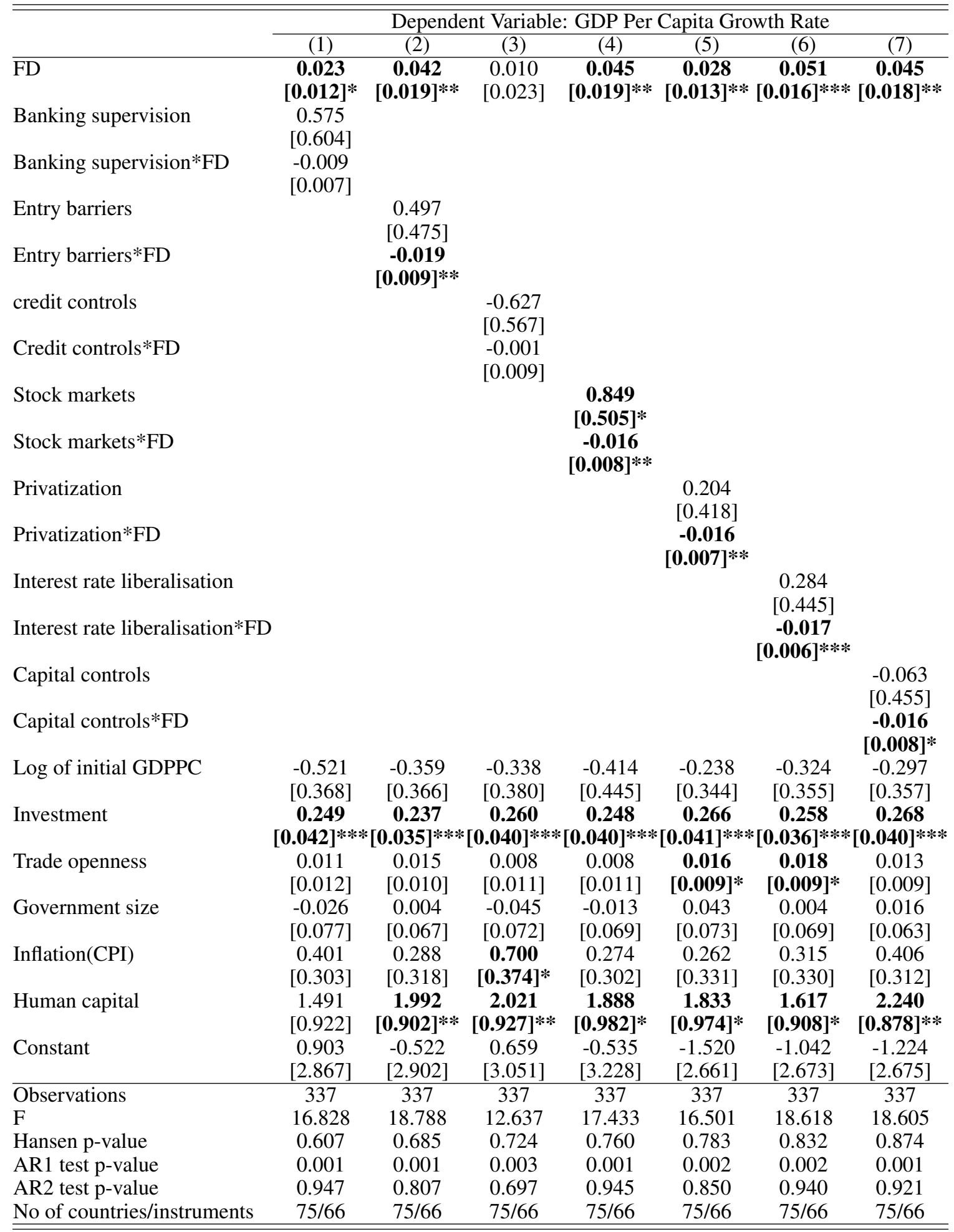

The table reports regression results (significant coefficients are written bold) for one-step system GMM after excluding outliers using Hadi (1992) method and robust standard errors are in brackets. $* \mathrm{p}<0.10$, ** $\mathrm{p}<0.05$, $* * * \mathrm{p}<0.01$. FD here is liquid liability ratio. FL index is taken from Abiad et al. (2008). 
the same positive significant effect as in Table 6. For our main FD indicator in Table 7, it remains significant at $1 \%$ level for all seven components of financial liberalisation. This remains intact for two-step system GMM as well.

But unlike the aggregate measure of financial liberalisation, three out of seven of its components show direct significant impact on economic growth in Table 7 . While the coefficient of banking supervision is positive and significant at 5\% level, credit control and capital control reforms show negative significant impact at $1 \%$ and $5 \%$ levels respectively. The rest of the components show no significant role in generating economic growth directly. In the case of private credit/GDP ratio, as reported in Table 8, the signs and significance remain the same for banking supervision and capital control reforms, but credit control reforms loose its significance. Instead stock market shows positive effect at 5\% significance level. For liquid liability ratio, the results are again different as shown in Table 9. Here, banking supervision does not show any significant effect, while we again observe negative significant effect for capital control reforms. Like in the privte credit/GDP ratio case, stock market reforms again shows positive significant effect.

The positive individual significant coefficient of banking supervision along with its negative interaction effect shows that a higher regulation up to a certain level has positive effects on economic growth, which shows that implementation of financial liberalisation policies with certain level of monitoring entails positive results in terms of higher level of long-run economic growth. This result makes perfect sense as certain level of banking supervision is necessary, but a very high level of the regulations may have adverse effects on the ability of banking sector to extend credit and to play its role in the economy and, therefore, may affect growth negatively. The negative significant coefficients for capital control reforms also suggest that there should be some control on capital movement internationally in order to achieve better effect of financial development and financial liberalisation.

\section{Further Robustness}

The foregoing analysis used the financial reform index calculated by Abiad et al. (2008) as the proxy for financial liberalisation where they calculated all components except banking supervision on the scale of 0-3, with higher value representing higher liberlisation (or, reform). But for banking supervision, they considered higher value as higher supervision (i.e., lower liberalisation). For this 
reason, financil reform index may not fully represent financial liberalisation. In order to address this and to check for further robustness, we re-calculate the financial liberalisation index that includes all seven of the components used in our original index calculated by Abiad et al. (2008), but this new index scales banking supervision in reverse order. That is, higher value on 0-3 scale on new index shows lessening of banking supervision rather than increasing the banking supervision as reform- as proposed by Abiad et al. (2008) in their original index. As our main index of financial reform uses banking supervision in reverse order, showing higher value of supervision as reform, we reverse this component to construct an index to get pure liberalisation perspective. For our new index higher values for all components including banking supervision show higher level of openness/liberalisation.

Table 10: Estimates using financial libearlization index

\begin{tabular}{lcc}
\hline \hline & $(1)$ & $(2)$ \\
& One-step System GMM & Two-step System GMM \\
\hline FD & $\mathbf{2 . 9 0 3}$ & $\mathbf{3 . 1 4 6}$ \\
FL & {$[\mathbf{0 . 9 1 8}]^{* * *}$} & {$[\mathbf{0 . 8 7 0}]^{* * * *}$} \\
FL*FD & 0.324 & -0.545 \\
& {$[2.143]$} & {$[1.752]$} \\
Log of initial GDPPC & $\mathbf{- 3 . 2 9 0}$ & $\mathbf{- 3 . 5 6 9}$ \\
& {$[\mathbf{1 . 1 9 0 0}]^{* * *}$} & {$[\mathbf{1 . 1 3 2}]^{* * * *}$} \\
Investment & -0.416 & -0.391 \\
& {$[0.481]$} & {$[0.377]$} \\
Trade openness & $\mathbf{0 . 2 3 9}$ & $\mathbf{0 . 2 5 7}$ \\
& {$[\mathbf{0 . 0 4 3}]^{* * *}$} & {$[\mathbf{0 . 0 4 4}]^{* * *}$} \\
Government size & -0.002 & -0.008 \\
& {$[0.011]$} & {$[0.010]$} \\
Inflation $(\mathrm{CPI})$ & -0.098 & -0.113 \\
& {$[0.096]$} & {$[0.080]$} \\
Education & 0.368 & 0.399 \\
Constant & {$[0.463]$} & {$[0.339]$} \\
& 0.949 & 1.282 \\
Observations & {$[1.079]$} & {$[0.827]$} \\
F & 3.777 & 4.472 \\
Hansen p-value & {$[4.141]$} & {$[3.138]$} \\
AR1 test p-value & 339 & 339 \\
AR2 test p-value & 7.856 & 8.706 \\
Number of countries & 0.327 & 0.327 \\
Number of instruments & 0.000 & 0.001 \\
\hline
\end{tabular}

Financial Liberalisation index is the normalised index incorporating our new supervision component. The reverse banking supervision is calculated by subtracting the actual value of the banking supervision indicator from its maximum value. The new banking supervision component ranges from $0-3$. The value 0 shows the least highest amount of banking supervision and 3 shows the least banking supervision. Standard errors in brackets. $* \mathrm{p}<0.10$, ** $\mathrm{p}<0.05, * * * \mathrm{p}<0.01$ 
Table 10 shows the results for the financial liberalisation index using reversed banking supervision component without outliers using one-step and two-step system GMM in columns 1 and 2 respectively. As expected the coefficient of financial development is highly significant for both models showing positive relationship between financial development and long-run economic growth. The interaction term between the new financial liberalisation index and our measure of financial development consistently shows negative significant coefficient, which supports our main resutls that higher level of liberalisation reduces the positive effect of financial development on economic growth. The financial liberalisation index on its own is not significant and most of the controls appear with similar signs and significance as before.

\section{Conclusion}

In this paper we investigate the conditional effects of financial development on economic growth, using financial sector liberalization as a conditioning variable. More specifically, we study the implications of financial liberalization interacting with financial development in impacting on economic growth. Our aim is to combine financial development, financial liberalization and growth through two testable hypotheses: first, the relationship between financial development and economic growth is conditional upon the level of liberalization in the financial sector; and second, an excessive level of liberalization is associated with a weak or negative effect of financial development on economic growth.

We employ a comprehensive measure of financial development by applying PCA on the fequently used measures of financial development across the time, while for robustness we use two most prominent among them: private credit to GDP ratio and Liquid-Libaiblity ratio. Further, we use a multiplicative interaction model to capture the conditional effects of financial development on growth which is estimated by employing one-step and two-step system GMM estimators to take account of country specific characteristics, as well as dynamics and endogeneity. We take care of influential outliers by applying the Hampel Identifier to the residuals obtained from each model.

Our regression results show that the marginal effects of financial development on economic growth is positive and significant, while the marginal effect of financial liberalization is generally insignificant. Further, the relationship between financial development and growth is conditional upon the level of financial liberlalization; that is, it decreases as the level of liberalization increases 
and even becomes negative at very high levels of liberalization. Thus, the negative interaction between financial development and financial liberalization suggests that at a very high level of liberalization adding more financial development may not be a growth promoting policy.

The results are consistent across all specifications with different definitions of financial development and for majority of the components of financial liberalisation index. Our results are also robust to the elimination of outliers and for our new index of financial liberalisation. The findings in this paper adds to the growing empirical work analysing the causes of the breakdown of the finance-growth relationship, particularly during the recent financial crisis. It suggests that relaxing the rules and regulations have amplified the impacts of inherent weaknesses in the financial system on the economies. The countries where financial liberalisation crosses a certain level the effect of financial development vanishes and can also become negative if financial liberalisation increases unabatedly.

On the policy front, our study sugests the followings: first, the governments should not go for excessive liberalization of the financial sector by removing the regulations too much in order to promote financial sector development with an expectation to foster growth; second, deragulation in the financial sector does not have automatic positive effect, instead government should always be watchful so that excessive liberalization does not take place.

\section{References}

Abiad, A., Detragiache, E. and Tressel, T. (2008). A new database of financial reforms.

Acharya, V. and Richardson, M. (2009). Causes of the financial crisis, Critical Review 21(23): 195-210.

Aghion, P., Howitt, P. and Mayer, D. (2005). The effect of financial development on convergence, Quarterly Journal of Economics .

Allen, F., Qian, J. and Qian, M. (2005). Law, finance, and economic growth in china, Journal of financial economics 77(1): 57-116.

Ang, J. B. (2008). A survey of recent developments in the literature of finance and growth, Journal of Economic Surveys 22(3): 536-576.

Ang, J. and McKibbin, W. (2007). Financial liberalization, financial sector development and growth: evidence from malaysia, Journal of Development Economics 84(1): 215-233.

Arcand, J., Berkes, E. and Panizza, U. (2012). Too much finance, Technical report, IMF Working Paper WP/12/161 http://www. imf. org/external/pubs/ft/wp/2012/wp12161. pdf. 
Arellano, M. and Bond, S. (1991). Some tests of specification for panel data: Monte carlo evidence and an application to employment equations, The Review of Economic Studies 58(2): 277-297.

Arellano, M. and Bover, O. (1995). Another look at the instrumental variable estimation of errorcomponents models, Journal of econometrics 68(1): 29-51.

Arestis, P. (2006). 21 financial liberalization and the relationship between finance and growth, $A$ Handbook of Alternative Monetary Economics p. 346.

Arestis, P. and Demetriades, P. (1997). Financial development and economic growth: Assessing the evidence*, The Economic Journal 107(442): 783-799.

Ayhan Kose, M., Prasad, E. and Terrones, M. (2009). Does openness to international financial flows raise productivity growth?, Journal of International Money and Finance 28(4): 554-580.

Bandiera, O., Caprio, G., Honohan, P. and Schiantarelli, F. (2000). Does financial reform raise or reduce saving?, Review of Economics and Statistics 82(2): 239-263.

Barro, R. J. and Lee, J. W. (2013). A new data set of educational attainment in the world, 19502010, Journal of development economics 104: 184-198.

Beck, T., Demirguc-Kunt, A. and Levine, R. (2009). Financial institutions and markets across countries and over time-data and analysis.

Beck, T. and Levine, R. (2002). Industry growth and capital allocation:: does having a market-or bank-based system matter?, Journal of Financial Economics 64(2): 147-180.

Beck, T. and Levine, R. (2004). Stock markets, banks, and growth: Panel evidence, Journal of Banking \& Finance 28(3): 423-442.

Beck, T., Levine, R. and Loayza, N. (2000). Finance and the sources of growth, Journal of financial economics 58(1): 261-300.

Beck, T. et al. (2000). Financial structure and economic development: Firm, industry, and country evidence, Vol. 2423, World Bank Publications.

Bekaert, G., Harvey, C. and Lundblad, C. (2011). Financial openness and productivity, World Development 39(1): 1-19.

Bencivenga, V. and Smith, B. (1991). Financial intermediation and endogenous growth, The Review of Economic Studies 58(2): 195-209.

Benhabib, J. and Spiegel, M. M. (2000). The role of financial development in growth and investment, Journal of economic growth 5(4): 341-360.

Bond, S., Hoeffler, A. and Temple, J. (2001). Gmm estimation of empirical growth models.

Caprio, G., Klingebiel, D., Laeven, L. and Noguera, G. (2005). Banking crisis database, systemic financial crises: containment and Resolution pp. 307-40.

Cojocaru, L., Hoffman, S. and Miller, J. (2011). Financial development and economic growth in transition economies: Empirical evidence from the cee and cis countries. 
Crotty, J. (2009). Structural causes of the global financial crisis: a critical assessment of the $\ddot{i} £$ new financial architectureï£ $;$, Cambridge Journal of Economics 33(4): 563-580.

Deidda, L. and Fattouh, B. (2002). Non-linearity between finance and growth, Economics Letters 74(3): 339-345.

Demetriades, P. and Hussein, K. (1996). Does financial development cause economic growth? time-series evidence from 16 countries, Journal of development economics 51(2): 387-411.

Demetriades, P. and Rousseau, P. (2011). The changing face of financial development.

Diaz-Alejandro, C. (1985). Good-bye financial repression, hello financial crash, Journal of development Economics 19(1): 1-24.

Easterly, W., Islam, R. and Stiglitz, J. E. (2001). Shaken and stirred: explaining growth volatility, Annual World Bank conference on development economics, Vol. 191, p. 211.

Edison, H. J. and Warnock, F. E. (2003). A simple measure of the intensity of capital controls, Journal of Empirical Finance 10(1): 81-103.

Favarra, G. (2003). An empirical reassessment of the relationship between finance and growth, Technical report, International Monetary Fund.

Grabel, 1. (1995). Speculation-led economic development: a post-keynesian interpretation of financial liberalization programmes in the third world, International Review of Applied Economics 9(2): 127-149.

Grant, J. (2010). What the financial services industry puts together let no person put asunder: How the gramm-leach-bliley act contributed to the 2008-2009 american capital markets crisis, Albany Law Review .

Greenwood, J. and Jovanovic, B. (1990). Financial development, growth, and the distribution of income, The Journal of Political Economy 98(5 Part 1): 1076-1107.

Guariglia, A. and Poncet, S. (2008). Could financial distortions be no impediment to economic growth after all? evidence from china, Journal of Comparative Economics 36(4): 633-657.

Hadi, A. S. (1992). Identifying multiple outliers in multivariate data, Journal of the Royal Statistical Society. Series B (Methodological) pp. 761-771.

Hadi, A. S., Imon, A. and Werner, M. (2009). Detection of outliers, Wiley Interdisciplinary Reviews: Computational Statistics 1(1): 57-70.

Hansen, L. P. (1982). Large sample properties of generalized method of moments estimators, Econometrica: Journal of the Econometric Society pp. 1029-1054.

Hellmann, T. and Murdock, K. (1995). Financial Sector Development Policy: The Importance of Reputational Capital and Governnance, Graduate School of Business, Stanford University.

Holzmann, R. (1997). Pension reform, financial market development, and economic growth: preliminary evidence from chile, Staff Papers-International Monetary Fund pp. 149-178.

Huang, Y. (2011). Determinants of Financial Development, Palgrave Macmillan. 
Jappelli, T. and Pagano, M. (2000). Saving, growth, and liquidity constraints, The Quarterly Journal of Economics 109(1): 83-109.

Jarrow, R. A. (2014). Financial crises and economic growth, The Quarterly Review of Economics and Finance 54(2): 194-207.

Kaminsky, G. and Schmukler, S. (2008). Short-run pain, long-run gain: Financial liberalization and stock market cycles*, Review of Finance 12(2): 253-292.

King, R. and Levine, R. (1993a). Finance and growth: Schumpeter might be right, The Quarterly Journal of Economics 108(3): 717-737.

King, R. and Levine, R. (1993b). Finance, entrepreneurship and growth, Journal of Monetary economics 32(3): 513-542.

Laeven, L., Igan, D., Claessens, S. and Dell'Ariccia, G. (2010). Lessons and policy implications from the global financial crisis, Technical report, International Monetary Fund.

Levine, R. (1997). Financial development and economic growth: views and agenda, Journal of economic literature 35(2): 688-726.

Levine, R., Loayza, N. and Beck, T. (2000). Financial intermediation and growth: Causality and causes, Journal of monetary Economics 46(1): 31-78.

Lucas, R. (1988). On the mechanics of economic development, Journal of monetary economics 22(1): 3-42.

McKinnon, R. (1973). Money and capital in economic development, Brookings Institution Press.

Móczár, J. (2010). Anatomy and lessons of the global financial crisis, Public Finance Quarterly 55(4): 753-775.

Odedokun, M. (1996). Alternative econometric approaches for analysing the role of the financial sector in economic growth: Time-series evidence from ldcs, Journal of Development Economics 50(1): 119-146.

Porta, R., Lopez-de Silane, F., Shleifer, A. and Vishny, R. (1996). Law and finance, Technical report, National Bureau of Economic Research.

Rajan, R. G. and Subramanian, A. (2005). What undermines aid's impact on growth?, Technical report, National Bureau of Economic Research.

Rioja, F. and Valev, N. (2007). Finance and the sources of growth at various stages of economic development, Economic Inquiry 42(1): 127-140.

Roe, M. and Siegel, J. (2008). Political instabilitys impact on financial development, Harvard Law and Economics Discussion Paper (570).

Roodman, D. (2006). How to do xtabond2: An introduction to difference and system gmm in stata, Center for Global Development working paper (103).

Roodman, D. (2009). A note on the theme of too many instruments*, Oxford Bulletin of Economics and Statistics 71(1): 135-158. 
Rousseau, P. and Wachtel, P. (2000). Equity markets and growth: Cross-country evidence on timing and outcomes, 1980-1995, Journal of Banking \& Finance 24(12): 1933-1957.

Rousseau, P. and Wachtel, P. (2011). What is happening to the impact of financial deepening on economic growth?, Economic Inquiry 49(1): 276-288.

Schumpeter, J. (1934). The theory of economic development: an inquiry into profits, capital, credit, interest and the business cycle (R. Opie, Trans.), Harvard University Press, Cambridge, MA.

Shaw, E. (1973). Financial deepening in economic development, Vol. 39, Oxford University Press New York.

Sinha, A., Kumar, R. and Dhal, S. (2012). Financial sector regulation and implications for growth, BIS Papers (62).

Soto, M. et al. (2009). System gmm estimation with a small sample.

Stulz, R. (1999). Globalization of equity markets and the cost of capital, Technical report, National Bureau of Economic Research.

Tressel, T. and Detragiache, E. (2008). Do financial sector reforms lead to financial development? evidence from a new dataset, IMF Working Papers pp. 1-42. 


\section{Appendix}

Table 11: List of Sample Countries

\begin{tabular}{llll}
\hline 1 & Albania & 45 & Kazakhstan \\
2 & Algeria & 46 & Kenya \\
3 & Argentina & 47 & Korea \\
4 & Australia & 48 & Kyrgyz Republic \\
5 & Austria & 49 & Latvia \\
6 & Azerbaijan & 50 & Lithuania \\
7 & Bangladesh & 51 & Madagascar \\
8 & Belarus & 52 & Malaysia \\
9 & Belgium & 53 & Mexico \\
10 & Bolivia & 54 & Morocco \\
11 & Brazil & 55 & Mozambique \\
12 & Britain & 56 & Nepal \\
13 & Bulgaria & 57 & Netherlands \\
14 & Cameroon & 58 & New Zealand \\
15 & Canada & 59 & Nicaragua \\
16 & Chile & 60 & Nigeria \\
17 & China & 61 & Norway \\
18 & Colombia & 62 & Pakistan \\
19 & Costa Rica & 63 & Paraguay \\
20 & Czech Republic & 64 & Peru \\
21 & Denmark & 65 & Philippines \\
22 & Dominican Republic & 66 & Poland \\
23 & Ecuador & 67 & Portugal \\
24 & Egypt & 68 & Romania \\
25 & El Salvador & 69 & Russia \\
26 & Estonia & 70 & Senegal \\
27 & Ethiopia & 71 & Singapore \\
28 & Finland & 72 & South Africa \\
29 & France & 73 & Spain \\
30 & Georgia & 74 & Sri Lanka \\
31 & Germany & 75 & Sweden \\
32 & Ghana & 76 & Switzerland \\
33 & Greece & 77 & Tanzania \\
34 & Guatemala & 78 & Thailand \\
35 & Hong Kong & 79 & Tunisia \\
36 & Hungary & 80 & Turkey \\
37 & India & 81 & Uganda \\
38 & Indonesia & 82 & Ukraine \\
39 & Ireland & 83 & United States \\
40 & Israel & 84 & Uruguay \\
41 & Italy & 85 & Uzbekistan \\
42 & Jamaica & Venezuela \\
43 & Japan & Zietnam \\
44 & Jordan & \\
\hline \hline & & & \\
\hline
\end{tabular}




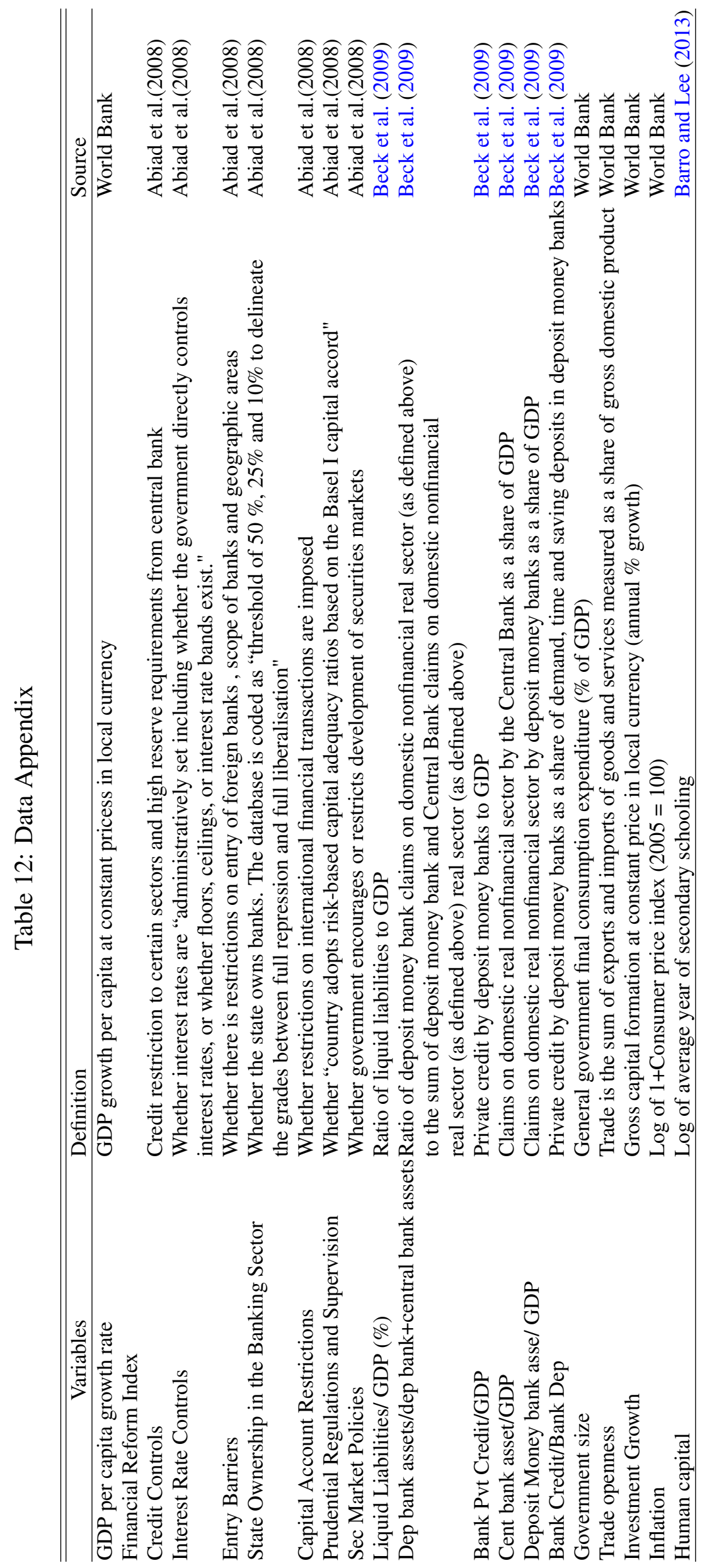


Table 13: Summary statistics

\begin{tabular}{|c|c|c|c|c|c|}
\hline Variable & Mean & $\begin{array}{l}\text { Std. } \\
\text { Dev. }\end{array}$ & Min. & Max. & $\mathbf{N}$ \\
\hline GDP per capita growth rate & 1.864 & 4.769 & -45.32 & 25.113 & 2644 \\
\hline Financial Reform Index & 0.496 & 0.304 & 0 & 1 & 2572 \\
\hline \multicolumn{6}{|l|}{ Financial Development } \\
\hline Liquid Liabilities/ GDP (\%) & 48.534 & 34.513 & 0.025 & 255.936 & 2259 \\
\hline Dep bank assets/dep bank+central bank assets & 81.956 & 18.358 & 9.122 & 100 & 2397 \\
\hline Bank Pvt Credit/GDP & 40.316 & 34.926 & 0.005 & 200.988 & 2331 \\
\hline Cent bank asset/GDP & 7.428 & 8.964 & 0 & 77.092 & 2239 \\
\hline Deposit Money bank asset/ GDP & 49.933 & 40.11 & 0.001 & 251.553 & 2337 \\
\hline Bank Credit/Bank Dep & 102.612 & 53.623 & 5.962 & 615.721 & 2478 \\
\hline \multicolumn{6}{|l|}{ Control Variables } \\
\hline Government size & 14.98 & 5.819 & 1.375 & 43.479 & 2573 \\
\hline Trade openness & 66.689 & 48.757 & 6.320 & 430.563 & 2595 \\
\hline Investment Growth & 4.896 & 19.079 & -376.2 & 223.084 & 2354 \\
\hline Inflation & 47.253 & 34.904 & 0 & 115.871 & 2426 \\
\hline
\end{tabular}

Table 14: Cross-correlation table for components of FD

\begin{tabular}{lcccccc}
\hline \hline Variables & LL/Y & BA/BCBA & PVT/Y & CBA/Y & DBA/Y & BC/BD \\
\hline LL/Y & 1.0000 & & & & & \\
& & & & & & \\
BA/BCBA & 0.3747 & 1.0000 & & & & \\
& $(0.0000)$ & & & & & \\
PVT/Y & 0.8722 & 0.5473 & 1.0000 & & & \\
& $(0.0000)$ & $(0.0000)$ & & & & \\
CBA/Y & 0.2181 & -0.5610 & -0.0704 & 1.0000 & & \\
& $(0.0000)$ & $(0.0000)$ & $(0.1679)$ & & & \\
DBA/Y & 0.9390 & 0.4929 & 0.9433 & 0.1079 & 1.0000 & \\
& $(0.0000)$ & $(0.0000)$ & $(0.0000)$ & $(0.0341)$ & & \\
BC/BD & 0.1163 & 0.2660 & 0.5281 & -0.2475 & 0.3042 & 1.0000 \\
& $(0.0236)$ & $(0.0000)$ & $(0.0000)$ & $(0.0000)$ & $(0.0000)$ & \\
\hline \hline
\end{tabular}

${ }^{1} \mathrm{LL} / \mathrm{Y}=\mathrm{Log}$ of Liquid Liabilities to GDP Ratio

${ }^{2} \mathrm{BA} / \mathrm{BCBA}=\mathrm{Log}$ of Deposits money bank assets to deposit money bank assets and central bank

${ }^{3} \mathrm{PVT} / \mathrm{Y}=\mathrm{Log}$ of Bank private credit to GDP ratio

${ }^{4} \mathrm{CBA} / \mathrm{Y}=\mathrm{Log}$ of Central bank assets to GDP ratio

${ }^{5} \mathrm{DBA} / \mathrm{Y}=\mathrm{Log}$ of Deposits money bank assets to GDP ratio

${ }^{6} \mathrm{BC} / \mathrm{BD}=\mathrm{Log}$ of bank credit to bank deposit ratio

${ }^{7} \mathrm{p}$-values in bracket 


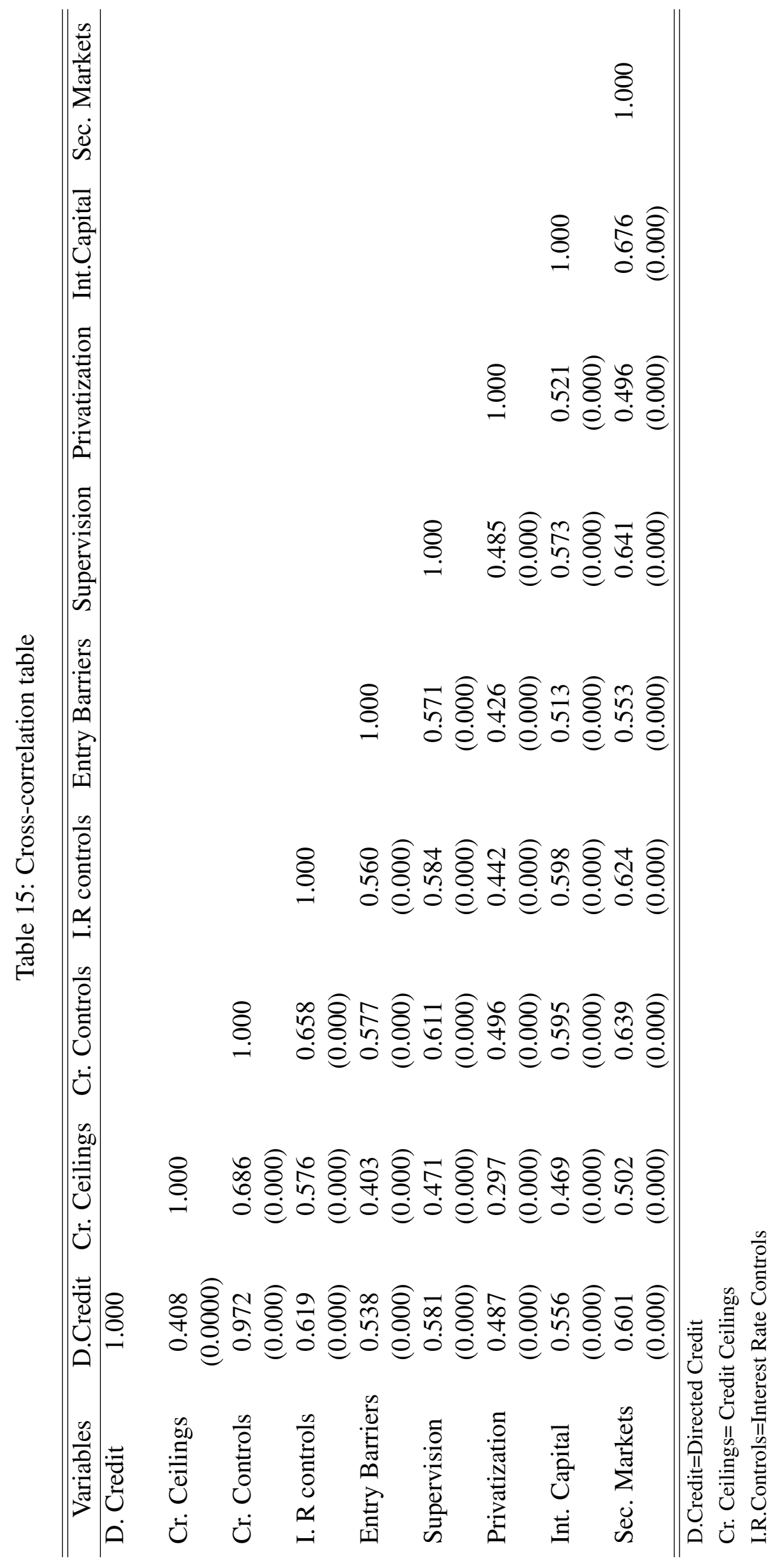


Table 16: Cross-correlation table

\begin{tabular}{|c|c|c|c|c|c|c|c|c|c|}
\hline Variables & GDPPCG & LLYo & FL & FD & Inv & TO & $\mathrm{G}$ & Inflation & Education \\
\hline GDPPCG & 1.0000 & & & & & & & & \\
\hline LLYo & $\begin{array}{c}0.0742 \\
(0.1082)\end{array}$ & 1.0000 & & & & & & & \\
\hline FL & $\begin{array}{c}0.2074 \\
(0.0000)\end{array}$ & $\begin{array}{c}0.5640 \\
(0.0000)\end{array}$ & 1.0000 & & & & & & \\
\hline FD & $\begin{array}{c}0.2666 \\
(0.0000)\end{array}$ & $\begin{array}{c}0.6378 \\
(0.0000)\end{array}$ & $\begin{array}{c}0.3740 \\
(0.0000)\end{array}$ & 1.0000 & & & & & \\
\hline Inv & $\begin{array}{c}0.5462 \\
(0.0000)\end{array}$ & $\begin{array}{c}-0.1577 \\
(0.0011)\end{array}$ & $\begin{array}{c}0.0152 \\
(0.7554)\end{array}$ & $\begin{array}{c}-0.1220 \\
(0.0192)\end{array}$ & 1.0000 & & & & \\
\hline TO & $\begin{array}{c}0.1513 \\
(0.0009)\end{array}$ & $\begin{array}{c}0.2388 \\
(0.0000)\end{array}$ & $\begin{array}{c}0.3528 \\
(0.0000)\end{array}$ & $\begin{array}{c}0.1959 \\
(0.0001)\end{array}$ & $\begin{array}{c}0.0107 \\
(0.8242)\end{array}$ & 1.0000 & & & \\
\hline G & $\begin{array}{c}-0.0962 \\
(0.0362)\end{array}$ & $\begin{array}{c}0.4509 \\
(0.0000)\end{array}$ & $\begin{array}{c}0.3073 \\
(0.0000)\end{array}$ & $\begin{array}{c}0.2743 \\
(0.0000)\end{array}$ & $\begin{array}{c}-0.1849 \\
(0.0001)\end{array}$ & $\begin{array}{c}0.1123 \\
(0.0151)\end{array}$ & 1.0000 & & \\
\hline Inflation & $\begin{array}{c}0.3163 \\
(0.0000)\end{array}$ & $\begin{array}{c}0.2597 \\
(0.0000)\end{array}$ & $\begin{array}{c}0.6637 \\
(0.0000)\end{array}$ & $\begin{array}{c}0.4062 \\
(0.0000)\end{array}$ & $\begin{array}{c}0.1133 \\
(0.0239)\end{array}$ & $\begin{array}{c}0.2585 \\
(0.0000)\end{array}$ & $\begin{array}{l}-0.0339 \\
(0.5034)\end{array}$ & 1.0000 & \\
\hline Education & $\begin{array}{c}0.0252 \\
(0.5894)\end{array}$ & $\begin{array}{c}0.7116 \\
(0.0000)\end{array}$ & $\begin{array}{c}0.6584 \\
(0.0000)\end{array}$ & $\begin{array}{c}0.3814 \\
(0.0000)\end{array}$ & $\begin{array}{l}-0.1184 \\
(0.0157)\end{array}$ & $\begin{array}{c}0.2333 \\
(0.0000)\end{array}$ & $\begin{array}{l}-0.2605 \\
(0.0000)\end{array}$ & $\begin{array}{c}0.3774 \\
(0.0000)\end{array}$ & 1.0000 \\
\hline
\end{tabular}

Note: GDPPCG=GDP per capita growth rate; LLYo $=\log$ of initial GDP per capita; FD=Financial Development; FD=Financial Development; Inv=Investment; $\mathrm{TO}=$ Trade openness; $\mathrm{G}=$ Size of Government. $\mathrm{p}$-values in bracket. 